\title{
Factors Affecting Sustainable and Quality Technical Vocational Training (TVT) Projects in Zambia
}

\author{
Article by Rodrick Sakamba \\ MBA, Texila American University, Zambia \\ Email: rsakamba@chresouniversity.edu.zm
}

\begin{abstract}
The purpose of this study is to investigate the factors affecting Sustainable and Quality TVT projects in public TEVET institutions in Zambia.

Furthermore, the present challenges on the Technical and Vocational training has jeopardized the sustainability for Education in terms of quality project Training Delivery and provision of good service in Zambia. Therefore, the good corporate Governance is a cornerstone and hallmark of any successful entity be in health business, education or indeed any other undertaking in any sector.

The Zambian Government introduced "Management Boards initiative" for it to survival and produce positive results; however, in an effort to fulfill this obligation, the Zambian Government has encountered obstacles and Globalization challenges that have considerably weakened its role. Therefore, the policy of the management board and lack of suitable curriculum development have attracted debate in the Technical and Vocational training sector.

This study is therefore, an attempt to identify and discuss problems and constraints responsible for the declining standards (provision of quality training delivery) or total quality assurance in the Ministry of Education Science Vocational Training and Education Early Child (MESVTEE) and recommend possible remedies.

The need for understanding the study was based on the concept of embracing sustainability as the life blood. The Methodology research was guided by a qualitative mode of inquiry called Action Research as the primary methodology. Action research is simply a form of selfreflective enquiry undertaken by participants. Thus, three selected public TEVET institutions were used as a case study and targeted 150 total samples population in Lusaka. The instruments used to collect data were questionnaires, focus group, interviews and observation schedules. Data collected were analysed qualitatively.

The study also looked at factors that could affect Sustainable and Quality Project Training Delivery (SQPTD) either positively or negatively such as political impact, globalization impact, and economic impact, social and environmental impacts. The study made known that the Ministry of Science Technology, Vocational Training and Education Early Child (MESTVTEE) has been neglected and instigated by a complex set of challenges which include; decentralization of operations in public TEVET institutions and mismatch between training and needs of industry. Furthermore, the study revealed that Zambian people need sustainable curriculum that can answer their current problems. 4

It also provided the information that, SQPTD is a philosophy of continuous improvement which can provide public TEVET institutions with a set of practical tools for meeting and exceeding present and future TEVET graduates needs, wants and expectations.

This study therefore was an attempt to identify and discuss problems and constraints responsible for the failure of embracing sustainability as the driving force of SQPTD. Thus, to overcome these challenges, the study examined a key number of issues:

- Disregard of Sustainable and Quality Project Training Delivery (SQPTD).

- Disregard of labour-market and high unemployment rate among TEVET graduates.

- Criticism of Public TEVET Management Boards performance

- Inadequate funding of TEVET projects

- and lack of accountability in TEVET institutions
\end{abstract}


South American Journal of Management

Special Edition 2016

- Inadequate of training materials for TEVET students.

Keywords: Public TEVET institutions and Sustainable and Quality Project Training Delivery (SQPTD) 5

\section{Introduction}

\section{Introduction}

The purpose of this chapter is to introduce the background to the study and its justification. It will further discuss the Theoretical frame work of the study and highlight the outline of the study.

\section{Background to the study}

Technical Education and Vocational Entreprenuership Training (TEVET) play a critical role in the economic development of a nation. Although, due to their dynamic nature, public TEVET institutions, industry and society are constantly subjected to the driving change forces. Additionally, it has been observed that the existence of dilemma in the Ministry Education Science Technology and Vocational Training Early Education (MESTVTEE) is the result of wrong decision and the failure to identify the department in the education system that deserves large portion of funding. Thus, this impasse has negatively impacted on Sustainable Quality Training Delivery (SQTD) in Zambia (Technical Vocational Training ipedia, 2000, $\mathrm{p} 1)$.

According to Technical Education, Vocational and Entrepreneurship Training (TEVET) News report (2011, p.3) the Zambian president Sata acknowledges that TEVET programmes have been neglected for a long time. It has not been receiving enough funding for improving access, quality and relevance of skills training through curriculum review. Curriculum review is vital more especially if it is able to enforce the Total Qualification Framework (TQF) which underpins the purpose of career progression path. Unfortunately the higher learning institutions such as University of Zambia and Cooper belt University are reluactly accepting TEVET graduates" credit transfers due to the fact that their curricula do not harmonize with each other. Thus, this challenge has continued due to lack of funding for curriculum review for both side.

Furthermore, Sata (TEVET New report, 2011, p. 3) affirms that "the majorities of our youths have poor education, have inadequate formal skills and consequently remain without jobs which would enable them to earn a living." Lauglo and Lillis (1988) stated that the bottleneck which has preoccupied many countries for a long time is whether to concentrate investment in General Education (GE) or Vocational Education (VE). But, in human capital terms, GE creates "general human capital" and VE leads to "specific human capital". The former has the advantage of flexibility and, therefore, the possibility of moving from one job to another, while the latter does not. Therefore, VE has the advantage of imparting specific job-relevant skills which make the worker more readily suitable for a given job and productive. Hence, both are important. It is in this light that most educational systems in African countries try to combine both general and vocational streams of education in varying proportions to suit their educational goals and aspirations. 17

Furthermore, although there had been a lot of effort directed towards improving Technical Education Vocational Entrepreneurship Training (TEVET) programmes in Zambia, the challenge still remains to the TEVET providers in Zambia due to the increase in demand for skilled personnel. According to Technical Education Vocational Entrepreneurship Training (TEVET) news report (2010, p.10) it has been revealed that TEVET providers have continued to produce half baked TEVET graduates. Hence, the industry has continued to re-train the TEVET graduates in order to enhance their effectiveness and efficiency particularly in their areas of specializations. Kanyansha the Technical Education Vocational Entrepreneurship Training Authority (TEVETA) Curriculum Development manager (TEVET News report, 
2009 , p. 10) affirms that "A curriculum which fails to take into account the needs of the industry will produce graduates who will fail to meet expectations from the same industry."

The decentralization of operations in TEVET providers is also the source of concern. For instance the Zambian Government introduced the decentralization of training delivery which has currently jeopardized Sustainable and Quality Training Delivery. The researcher strongly believed that the move was political in the sense that the Government was too quick to implement decentralization of operations. However, it is vital to introduce the concept of decentralization of operations if adequate infrastructure, equipment and the latest technology are available in all 24 public TEVET institutions (TEVET news report, 2012, p.15).

Nevertheless, the economic standard of living has to be raised in Zambia, Sustainable and Quality Vocational and Skills Training would be the key for industrialization and computerization. It is not only about mass schooling or wide expansion of TEVET institutions and acquiring qualifications, but it is about economic needs for quality human capital that reinforces sustainability in the informal and formal sectors. Thus, the issue today in Zambia is not so much about the magnitude of TEVET but how to ensure its relevance, responsiveness and value in an increasingly global economy. Hence, there must be national standards in a training process and certification for improvement of quality and effectiveness in TEVET to meet the demands of labour market in and outside country. 18

\section{Statement of the problem}

There had been a lot of effort directed towards sustainable and quality training delivery Projects in the Technical Education Vocational Entrepreneurship Training (TEVET) programmes in Zambia. Despite these efforts the challenge still remains to all 24 public TEVET institutions in Zambia due to the increase in demand for skilled personnel. According to Technical Education Vocational Entrepreneurship Training (TEVET) news report (2010, p.10) it has been reported that TEVET providers have continued to produce half baked TEVET graduates. Hence, the industry has continued to retrain the TEVET graduates in order to enhance the effectiveness and efficiency of their performance mainly in their areas of specialization.

Furthermore, the core competences of public TEVET management boards are also the source of concern due to rapid new changes in the Quality Management System Implementation Policy (QMSIP) of Monitoring and Evaluation (ME) in the public sector. For instance the new rapid change was the decentralization of Training projects operations and the introduction of the management boards in all 24 public TEVET institutions in Zambia, regrettably this change has jeopardized Sustainable and Quality Training projects Delivery because the public TEVET providers still have outdated equipment, poor infrastructure and workshops due to inadequate funding (TEVET news report, 2010, p. 4).

Currently, the curricula harmonization is another critical challenge, since 1998 a series of TEVET programmes have outdated syllabi due to inadequate funding for curriculum review project; hence the Total Qualification Framework (TQF) has disastrous integrated into higher learning curricula (TEVET news report, 2012, p.15).

Nevertheless, the economic standard of living has to be raised in Zambia, sustainable and quality Vocational and Skills Training projects would be the key for industrialization and computerization. It is not only about mass schooling or wide expansion of TEVET institutions and acquiring qualifications, but it is about economic needs for quality human capital that reinforces sustainability in the informal and formal sectors and effective TEVET TQF for the purpose of career progression path.

\section{Research questions}

The study required to answer the following key research questions:

1. What are the problems and constraints affecting Sustainable and Quality projects Training Delivery (SQPTD) in Lusaka? 
South American Journal of Management

Special Edition 2016

2. What are the capabilities of Public Technical Education Vocational Technology Entrepreneurship Training Institutions (PTEVTETIs) in executing SQPTD?

3. How do you sustain Quality Management System Implementation Projects in PTEVTETIs?

\section{Overall Objective}

The overall objective of this thesis is to investigate problems and constraints affecting Sustainable and Quality Technical and Vocational Training (TVT) projects in Zambia.

\section{The specific objectives are}

1. To identify the problems and constraints affecting Sustainable and Quality Training Delivery in Lusaka.

2. Discuss the capabilities of public Technical Education Vocational Technology Entrepreneurship Training institutions in Lusaka.

3. To assess how to sustain projects of Technical Education Vocational Technology Entrepreneurship Training in terms of Quality Management System Implementation.

4. To provide recommendations to public Technical Education Vocational Technology Entrepreneurship Training institutions on how to sustain Quality and Training Delivery.

\section{Significance of the Study}

It is hoped that the end result of this study will help out in identifying the numerous and complex problems of Public TEVET institutions, thereby upholding the TEVET policy, fascinating Public TEVET employees and increasing the knowledge of Sustainable Quality Projects Training Delivery (SQPTD). Furthermore, the study will provide suggestions and recommendations to address Quality Management System Implementation (QMSI).

\section{Scope of the study}

The study area will be confined to a case study of three public TEVET institutions in Lusaka. It will identify problems and constraints affecting Sustainable and Quality Projects Training Delivery.

\section{Structure of the study}

Chapter one; The purpose of this chapter was to introduce the background of the study statement of the problem, research questions ,all over objective, specific objectives, significant of the study, scope of the study and structure of the study.

Chapter two; Literature Review will be introduced and discuss factors affecting Sustainable and Quality Technical Vocational and Training and capabilities of Management Boards in executing SQPTD in various public TEVET institutions.

Chapter three; It will describe the methodology that the researcher will apply in this study. Action research, research design, the sample selection and data collection process. Ethical considerations and research limitations 20

Chapter four; will discuss the findings of the study.

Chapter five; will analyze the results and discuss the analysis of data collected of its validity and reliability of findings.

In chapter six; will provide conclusion and recommendations for stakeholders of public TEVET institutions

\section{Conclusion}

This chapter has outlined the background of the study. It discusses the statement of the problem; it brings out research questions, all over objectives and the specific objectives, significance of the study, scope of the study and the structure of the study. The next chapter will discuss the literature review on factors affecting Sustainable and Quality Projects in public institutions. 21 


\section{Theoretical framework of the study}

Black (1993: 25) defines theories as explanations of how things function or why events occur. Hussey and Hussey (1997: 123) define theoretical framework as a collection of theories and models from the literature which underpins a positivistic research study. Therefore, theoretical framework is a foundation for the parameters or boundaries of a study. Once these themes are established, researchers can seek answers to the topical questions they have developed on broad subjects and stay on point of the study tightly within the theme or topic. The study will build upon the understanding of key words such as TEVET policy, Ministry of Education and Science, Technology and Vocation Training and Early Education (MESTVTEE), TEVET Management Boards (TEVET MBs), Sustainable and Quality Projects Training Delivery (SQPTD) ,Total quality management (TQM) and Strategic Development for MESTVTEE. 22

Figure 1. Sustainability holding Society and public TEVET institutions - Model

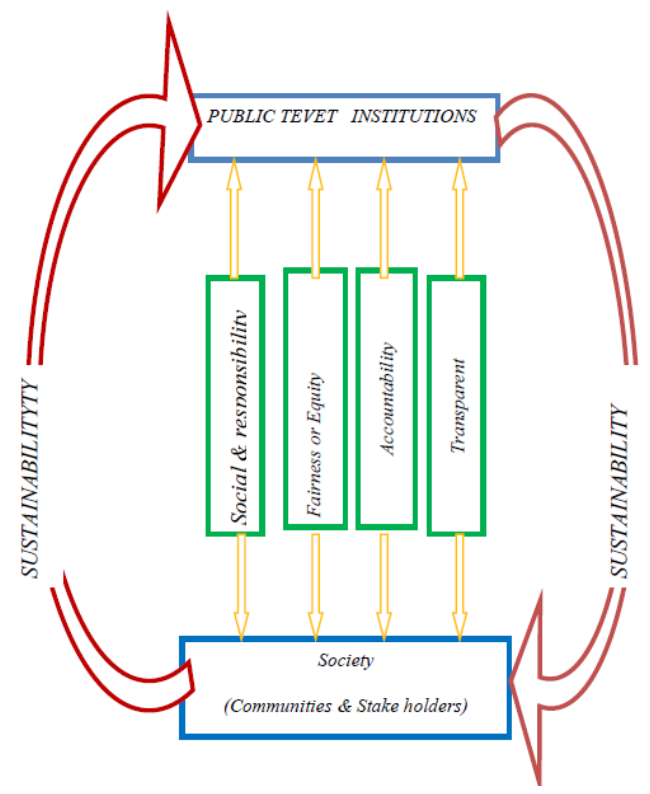

Source: own 23

\section{Interpretation of the Diagram (Sustainability holding public TEVET institutions and Society).}

Figure 1 diagram shows how sustainability "holds" public TEVET institutions and society. There are four main features of good Governance that supports public TEVET institutions and Society. These four features include social responsibility, equity, accountability and transparent. Sustainability can be perceived as the "framework" holding public TEVET institutions projects and society. Public TEVET institutions and society are part of the framework which is supported by four main features of good governance. Sustainability strives for quality. Both Quality and Good governance are concerned with external and internal satisfaction. Sustainability is the critical thinking and reflection. It is the unique mental angle. The unique mental angle is a unique idea, and that unique idea is to serve others (society) without impartiality. Therefore, sustainability is the concept that needs to be understood on how it influences training delivery in all areas of education such as sustainable quality training delivery, sustainable curriculum review and sustainable Total Qualification Framework (United Nations 2004, p.1). Good governance is to serve others without impartiality. Good Governance relies on sustainability. Sustainability enhances commitment and promotes quality project training delivery. The features that can be used by stakeholders of public TEVET institutions are shown in figure 1 for executing actions upon sustainability. 
South American Journal of Management

Special Edition 2016

Figure 1 indicates that nothing can work without sustainability; nothing can move without sustainability, nothing can improve without sustainability and nothing can change without sustainability. Therefore, stakeholders and the public TEVET staff have a major role in embracing sustainability as a driving force in order to avoid producing half baked TEVET graduates (Robert et al 2002). 24

\section{Conclusion}

This study looks at how TEVET system should be carried out and assists society in embracing sustainability for quality training delivery. It is also important to note that sustainability can serve as enabler and driver of green human resources development in the fulfillment of short and long- term goals. Furthermore, sustainable and quality has become a key in this millennium and contributes significantly to attaining the UN Millennium Development Goals (MDGs) and leapfrogging to the achievement of the objectives of the Decade of educational for sustainability development (DESD) (2005 -2015). Similarly in TEVET System, Zambian government has set out some objectives in the implementation of Vocational Training for sustainability.

TEVET systems play a crucial role in the economic development of a nation. Thus, the new knowledge the researcher wishes to put across is to ensure that the Government officials and those politicians in Government uphold sustainability as the framework for quality training delivery. Sustainability holds all public TEVET institutions and overcomes those factors which can negatively affect quality training delivery. One of these negative factors is inadequate funding for skills training. However, public TEVET Management Boards (MBs) as well must recognize that they are accountable for the resources made available to them by the state. Educators in public TEVET institutions should be accountable to the other stakeholders for what they do. Nevertheless, if public TEVET lecturers, trainees, parents and the wider community are accepted as stakeholders of TEVETsystem, the decision on what happens in public TEVET institutions and how it is done would not be the exclusive prerogative (privilege) of any one group, although some public TEVET Management Board members might have a greater say than other stakeholders. 25

\section{Literature Review}

\section{Introduction to the Literature Review}

Cooper and Schneider (2001, p. 23) state that Literature Review examines recent or historically significant research studies, company data, or industry reports that act as a basis for study. Creswell $(2009$, p. 23) affirms that Literature Review helps to establish whether the topic is worth studying or not, and it provides insight into ways in which the researcher can limit the scope to a needed area of inquiry.

Veal (1997, p. 9) further defines literature review as an evaluation report of information found in the literature related to your selected area of study. The review should describe, sum up, evaluate and clarify this literature. It should give a theoretical base for the research and help the researcher to determine the nature of the research. Furthermore, Shuttle worth (2009, p. 1) agreed that identifying relevant literature is a demanding task.

This chapter, however, will cover existing literature concerning problems and constraints affecting sustainable and quality TEVET system in Zambia. It will go further by identifying and analyzing the challenges affecting public TEVET institutions and by investigating how TEVET sustainability has been successively executed in Zambia.

\section{Major problems and constraints in public TEVET institutions in Zambia}

\section{Introduction}

Within the early 2000s, numerous concerns were raised due to new challenges such as social economic impact, globalization impact, regionally impact and SQTD challenges in 
public TEVET institutions. As mentioned above the consequences of these major problems and constraints can be subdivided into the following challenges:

- Disregard of Sustainable and Quality Training Delivery (SQTD).

- Disregard of labour-market and high unemployment rate among TEVET graduates.

- Criticism of Public TEVET Management Boards performance

- Inadequate funding

- Lack of accountability

- Inadequate of training materials.

In an attempt to address these challenges, the researcher argues that the public TEVET institutions need to embrace sustainable and quality in order to align the TEVET programmes with market, especially the industry. Furthermore, public TEVET institutions are suffering from misappropriation of Government funds, misconception, and mis-match and mishandling the core competence of the sector.

TEVET is also regarded as the second or third or the last option for youth. Thus, Vocational training has been looked down upon as the options for those who are not able to take up higher education. For example, in Zambia TEVET has no curriculum that has link with all Government Universities such University of Zambia and Copper belt University. Therefore currently, there is no effective career path progression for TEVET graduates.

The researcher observed that white colour jobs are the most sought after while blue colour jobs in Zambia. Thus, TEVET graduates jobs are regarded for people with no other options.

Lwalanda (2007) in Uganda also noted that, "the reason why TEVET and sustainable and quality are not valued in developing countries is just because educated rate it to be for failures. Additionally, there is very little concern of skills training in the early years of children' s education which makes them hate technical education. Thus, even in Zambia this education is regarded as for failures in the academic path and the parents" only resort to it when their children fail.

Nevertheless, the researcher affirms that to achieve green TEVET curricula in Zambia, the MESTVTEE must focus on outcomes in the skills, knowledge and attitudes required in the industry. That is to say, MESTVTEE should be responsive to the demand of industry.

\section{Integration of Sustainable and Quality Project Training Delivery (SQPTD)}

The phrase sustainable development is often abbreviated to the single word called "sustainability." However, the Brundtland Report (world commission on Environment and Development, 1987), commissioned by the United Nations to examine long - term environmental strategies, argued that economic development and environmental protection could make compatible but that would require quite fundamental changes in economic practices throughout the world.

United Nations (1987) defined Sustainable development as: "development that meets the needs of the present without compromising the ability of future generations to meet their own needs. Thus, sustainable strives for quality and not the number of TEVET institutions. 27

According to Welford (1993), sustainable development is made up of three closely connected issues and associated conditions. This includes:

- Environment: This must be valued as an integral part of the economic process and not treated as a free good. The environmental stock has to be protected, which implies minimal use of non- renewable resources and minimal emission of pollutants. The ecosystem has to be protected so that the loss of plant and animal species has to be avoided.

- Equity: One of the biggest threats facing the world is that the developing countries such as Zambia, want to grow rapidly to achieve the same standards of living as those in the west. That in itself would cause a major environmental disaster if it were modeled on the same sort of growth as experienced in post - war Europe.

Therefore, there must be needs of a greater degree of equity and the key issues of poverty to be addressed, but it seems there is hypocritical for the west to tell the third 
world (Zambia) the truth that they cannot attain the same standards of living and consumption, due to the fact that developing countries are still lacking behold in terms of technology.

- Positivity: Sustainable development requires that society; public TEVET institutions and individuals operate on a different time scale than that which currently operates in the economy. While institutions commonly operates under competitive pressures to achieve short term gains, long - term, intergenerational considerations are observed, longer planning horizons need to be adopted and the TEVET policy needs to be proactive rather than reactive. Unfortunately, the Brundtland Report concludes that these three conditions are not being addressed in Africa.

\section{Quality Project Training Delivery (QPTD)}

President of Hewlett- Packard, Fortune (1985,) argues that in today' s competitive environment, ignoring the quality issue is tantamount to corporate suicide. Thus, public TEVET institutions should continually meeting trainee needs or what it takes to satisfy the trainee or simply fitness for purpose.

In Helene Giroux article on management fashions (2006) added that if quality is perceived as merely meeting technical specification only mediocre results will be achieved.

Juran and Gryn (1989) argued that quality means internal and external trainee (customer) satisfaction.

Nevertheless, a comprehensive definition of quality is provided by Galgano (1994), "quality, therefore, includes the following: competitiveness; deliver; cost; morale; productivity; profit; product quality; quantity or volume; performance; service; safety; concern for the environment and the stockholders interest. 28

Quality in service industries such as public TEVET institutions are more challenging to define because of three features unique to services" intangibility, heterogeneity, and the inseparability of production and consumption (Parasuraman et al, 1885).

Schneider and White (2004, p. 41) have provided some definitions as quoted from authors for considerations of quality as: "Quality is a consumer - generated comparative judgment, since individuals have no implicit sense of quality a standard is of comparison is provided" (Oliver, 1997, p. 163).

Quality is the extent to which the service process and the service organization can satisfy the expectations of the user. Service quality has been recognized as a key factor in differentiating service products. Therefore, trainee satisfaction can be secured through high quality training delivery.

Mushala (2011, p. 5) defines QMS as the recipe which ensures that the degree of superiority specified in QMS is attained. It is the sum of the activities and information an organization uses to enable it to better and more consistently deliver the products and services that meet and exceed the needs and expectations of its customers and beneficiaries, more cost efficiently, today and in the future.

The main purpose of QMS is about creating a "quality" culture across an organization, key consideration to QMS is continual improvement in quality, today and in the future.

QMS is more than assuring quality today. It is about maximizing the ability of the organization to consistently deliver quality products and services into the future. Nevertheless, Quality Assurance, Quality Audit and Quality Control are elements of QMS, but not the totality of the System. However, Quality Assurance does not essentially lead to achieving quality.

In the words of Mushala, quality is achieved efficiently when activities and related resources are managed as a process. Thus, for this to happen there is need for a systematic and planned approach. The system must have clearly defined processes and procedures that meet agreed requirements for the delivery of services. 
In this way, the outcome of the process meets quality requirements and achieves customer satisfaction. However, it has been observed that both QMS and TQM mean customer satisfaction. Hence, they are interrelated in execution.

Public TEVET institutions in Zambia have a major challenge to prepare the present and future workforce especially those belonging to Small and Medium Size Enterprises (SMESs). Thus, to prepare the present and future workforce the Sustainable and Quality TEVET is the key to quality TEVET graduates (TEVET news Report, 2011, p.6). 29

The researcher strongly believes that public TEVET institutions which are not yet implemented TQM and total quality- related instruction in their curriculum/ training programmes have a major responsibility to commence Sustainable and Quality Project Training Delivery (SQPTD) and developing their present and future workforce through the addressing of TQM concepts and associated methodologies for continuous improvement of the learning process. Furthermore, the major concern by the researcher is how to respond to problems and constraints affecting sustainable and quality in public TEVET institutions in Zambia.

The researcher observes that Zambia has continued to face challenges in how to sustain quality in public TEVET institutions despite the commitment to liberate youths through practical skills training.

\section{Sustainable and Quality TEVET curriculum}

\section{Introduction}

Taneja (2012, pp. 292-295) defines a curriculum as the instructional and the educative programme by following which the students achieve their goals, ideals and aspirations of life. The function of the curriculum can be made strikingly clear by regarding it as a road or a highway.

In the words of Taneja summaries that Curriculum is dynamic and not static. It has to be constantly changing according to changing needs, demands and aspirations of society. Furthermore, curriculum is the reflection of the aims of Education. Therefore, the Sustainable and Quality TEVET curriculum is the prerequisite of the Qualification Framework (TQF). According to TEVET News report (2010, p. 7) TEVET Qualification Framework (TQF) has been developed in order to enhancing career path for TEVET graduates in Zambia. Despite, the inadequate funding for curriculum review projects by the Government.

The TEVET Qualifications Framework (TQF) has finally been launched with a call to ensure that training standards and quality are upheld. TEVETA Board Chairman, Kalabo (2010, p. 8) said that, introduction of TQF ensures that the nation benefits from the skilled human resource that training providers continue to churn out onto the industry. Furthermore, the TEVET Qualification will enhance and build on what has been achieved over the past years in the TEVET institution, by taking into account the skills needs of the future.

Revitalize strategy (TVET 2007, p. 43) states that another significant step in the TEVET policy implementation process is the development of a National Vocational Qualifications Framework (NVQF). Furthermore, the development of a qualifications framework is a monotonous and arduous exercise that requires the participations of employers, industry experts, and technical teachers. 30

Nevertheless, an NVQF will prescribe proficiency requirements, qualification levels, as well as validation and certification standards. Although an NVQF is normally tailored to a country "s technological profile, it is necessary to keep in mind the need to link up national qualifications frameworks with regional frameworks. The objective here is to increase the portability of TEVET qualifications across national frontiers, such that TEVET becomes a factor of regional integration (Revitalize strategy TVET 2007, p. 43).

The researcher argues that despite that the Qualification Framework TQF has been introduced in Zambia, TEVET programmes are still considered for the less academically endowed. Thus, this perception has been fuelled by Government itself by stating that the primary objectives of the Vocational Training is the track to keep dropouts or "lockouts" 
South American Journal of Management

Special Edition 2016

students who are unable to move up the educational ladder, not because of poor grades but because of lack of places at the higher level (TEVET News report, 2010, p. 7)

Furthermore, the researcher noted that TEVET graduates find it difficult if not impossible entering the Vocational Education stream to proceed to higher Education. TEVET Qualification Framework (TQF) which was introduced in 2010 has no effective direct link or progression to higher education in Zambia. For instance TQF level 6 which is the highest level of a three years Diploma has no efficient career progression path to any Government University in Zambia. Thus, it is still impossible to make TEVET less dead end in Zambia.

The researcher affirms that higher learning institutions complain that the curriculum of TEVET does not harmonize with the Government Universities in Zambia. Thus, it has been noticed that although TEVETA has already designed the progression career path for TEVET graduates it is still impossible for TEVET graduates to have access to higher learning institutions.

"In Africa, we are very good at drawing up strategies and plans but when it comes to implementation, there is always a difficult" (Revitalize strategy TVET 2007, p. 41).

The researcher concluded that some programmes of TEVETA do not even excite in public universities such as Degrees in Hospitality Management. Unfortunately, currently all Government Universities are not yet ready to introduce Hospitality Degrees in Zambia.

It is for this reason Private Universities took advantage to introduce Hospitality Degrees programmes although their QTD is still questionable due to the fact that the practical aspect of the training is not applied. Thus, $98 \%$ of their training is on theory aspect. Furthermore, the major challenge of TEVET TQF is the TEVET curriculum review which is not adequately revised since 1998. 31

Therefore, Figure 2 denotes the current career progression path for TEVET graduates in Zambia.

Figure 2 Career progression path for TEVET graduates in Zambia

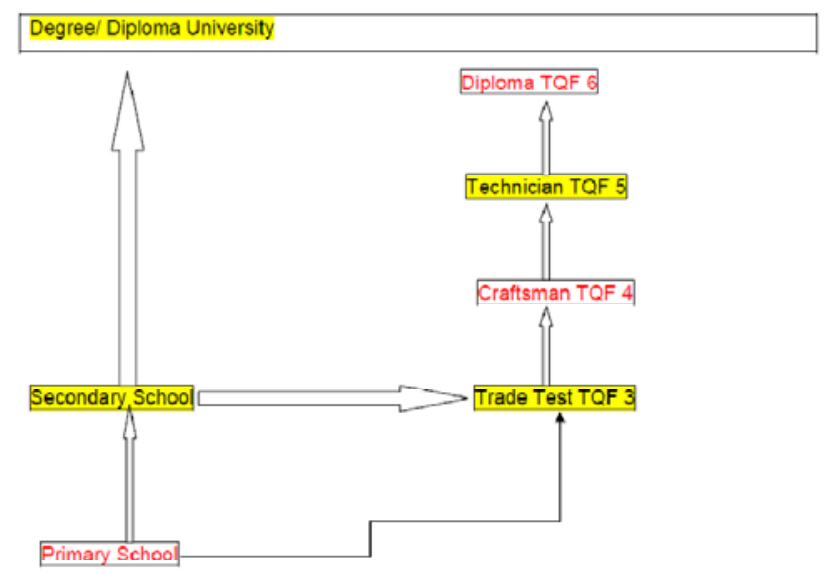

\section{Research Methodology}

\section{Research Methodology}

Creswell (2003) defines research methodology as the procedural rules for the evaluation of research claims and the validation of the knowledge gathered.

This research will be guided by a qualitative mode of inquiry called Action Research as the primary methodology. Action research is simply a form of self-reflective enquiry undertaken by participants in social situations in order to improve the rationality and justice of their own practices, their understanding of these practices, and the situations in which the practices are carried out (Carr and Kemmis 1986, p. 162). 


\section{Overview}

Action Research has its origin in the works of the social psychologist Kurt Lewin (1946). He developed the ideas of group decision and commitment to improvement at work situations (classroom and administrative). It is an act of analyzing a situation leading to certain action for improvement and evaluating the result of the tried out action. Action research is focused on immediate application. It places the emphasis on the problem here and now, in a school setting. Its findings are to be evaluated in terms of local applicability and improvement in school practices. The whole purpose of Action Research is to involve classroom teachers to attempt to solve their classroom problems.

\section{Rationale for Action research methodology}

The researcher strongly believes that the heart of action research is to learn from your experience and apply that learning to bring the change in society. Action research is more applicable than main streams research methods in situations requiring responsiveness and flexibility and action. Thus, action research is more relevant for practioners or specialists of Vocational Training.

The best reason for choosing it is that it fits the researcher' s preferences to ensure that the society and stakeholders embrace the sustainability as the life blood (Lewin 1948). Warican (2000, p. 2) argues that the core goal of action research is to create sustainable learning capacities and give participants the option of increasing control over their own situation.

Edge (2003, p. 39) saw action research as a rigorous investigation which sets out to improve the sustainable and quality training delivery base on experience and outcome available to participants in a given situation. Furthermore, action research can help a researcher to fill the gap from theory to practice in the vocational training (Mc Niff, Lomax Whithead 1996, p. 13) 33

\section{Process on the Action Research cycle}

Action research is the process of systematic collection and analysis of data in order to make changes, improvement and solve challenges affecting SQDT in public TEVET institutions (Wallace 1998: 1 and Quirke 2001, p. 14). Nunan (1992, p. 19), Nunan (1993, pp. 41- 42) and Bailey, Curtis and Nunan (2001, p. 137) described the process of action research as a series of step:

Figure 5 Steps on the Action Research cycle

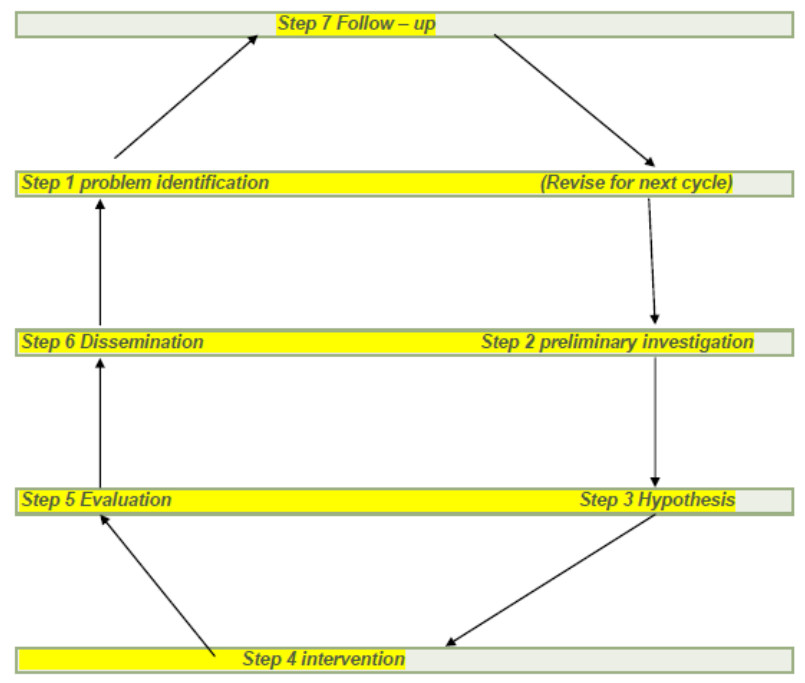

Source: Nunan (1992, p. 19) 34

Step 1: Problem Identification. 
Researcher identified problems that had occurred in the public TEVET institutions from previous experience.

\section{Step 2: Preliminary Investigation.}

Researcher further investigated public TEVET lecturers" feelings towards their problems and consulted other departments about problems.

\section{Step 3: Hypothesis.}

Researcher formed the hypothesis that most stakeholders in the public TEVET institutions lacked ability to embrace sustainability as a life blood, because they had developed negative attitudes toward Sustainable and Quality Training Delivery (SQTD).

Step 4: Intervention.

After observing the challenges of public TEVET institutions and forming the hypothesis, the researcher identified strategies that could solve problems defined by the hypothesis.

\section{Step 5: Evaluation.}

In this step, the researcher worked through the stages of: act, observe, reflect and revise to evaluate the TEVET policy outcomes in terms of activities, materials, classroom atmosphere and Management Board"s (Mob's) role.

Step 6: Dissemination. Reporting the results was the focus of this step.

\section{Step 7: Follow-up.}

Changing to improve for the next cycle was discussed in this step.

Farrell (2002: 25) provides six ways of sharing private reflections with others: getting a group of lecturers together to talk about SQTD, collecting data from public TEVET lecturers and other members of public TEVET institutions and sharing this data with the group for discussion, self observation in the actual environment, journal writing for reflection and comments by group members (see appendix A ). 35

\section{Limitations of Action Research}

Ghosh (2008) observed some of the costs of choosing action research as the research paradigm:

1. Within psychology this is a greater issue for fourth year theses than it is at Masters Level and beyond. It is also more of a source of difficulty in academic psychology than in many other disciplines.

2. You probably can' t use a conventional format to write it up effectively. Again, that means you have to learn some new skills.

3. In psychology there is a strong expectation that the format recommended by the American Psychological Association (APA) will be used. A non-APA format may alienate some examiners. Again, this may be more of an issue for people working within the discipline of psychology than in some other social sciences. However, most disciplines have their ideologies about how research should be reported.

4. The library work for action research is more demanding. In conventional research you know ahead of time what literature is relevant. In most forms of action research, the relevant literature is defined by the data you collect and your interpretation of it. That means that you begin collecting data first, and then go to the literature to challenge your findings. This is also true of some other forms of field research, though certainly not all.

5. Action research is much harder to report, at least for thesis purposes. If you stay close to the research mainstream you don' thave to take the same pains to justify what you do. For action research, you have to justify your overall approach. You have to do this well enough that even if examiners don' $t$ agree with your approach. They have to acknowledge that you have provided an adequate rationale. (This may be true for other methodologies outside the research mainstream too.)

6. An action research thesis is likely to be longer than a conventional thesis. As already mentioned, you have to provide a more compelling justification for what you do. In effect, you have to write two theses. One reports your method, results and 
interpretation. The other explains why these were appropriate for the research situation. In addition, if you use qualitative data (and you probably will) that also tends to take more space to report.

\section{Advantages of Qualitative methodology}

The difference between action research and other researches is in emphasis, not in the method or spirit. However, there is a need to understand how it differs from other researchers. Action research is the research undertaken by practitioners so that they may improve their practices. It has most of the characteristics of fundamental or applied research. But its methodology is not a rigorous as that of fundamental or applied research. 36

The findings of action research are evaluated in terms of local applicability. The application of findings is "here" and "now". Action research is not a library project in which you learn about a particular topic by collecting information from either the books available in the library or by using the Internet. For example, if you want to undertake a project about finding out the „life during the Indus valley civilization“, then you would go to the library, collect the relevant data and write the report in the narrative form.

Action research also does not aim at finding solution to the problem in the sense of trying to find out what is wrong, but rather its aim is to suggest the measures about how to improve one' s own situation.

\section{Research Design - Case Study Design}

Young (ref) describes that case study as a method of exploring and analyzing the life of a social unit, a person, a family, an institution, cultural group or even the entire community. Case study has its roots in clinical observation. It is diagnostic in nature. It is a form of qualitative analysis involving a very careful and complete observation of a person, a situation or an institution. For recording what is being observed a case-study sheet is developed which documents the identity of the subject, the problem, observations made, planning of remedial action and findings.

Cooper and Schindler (2003), state that a research design is the blue print for fulfilling objectives and answering questions. Research designs are about organizing research activities, which include the collection of data, in ways that are most likely to achieve the research aims. However, this research design includes ontological and epistemological issues on how society should move towards SQTD (Bakisa, 2008, p. 1). Thus, the following are the issues concerning research design ontology and research design epistemological:

\section{Research Design ontology}

According to Yin (2002) case studies are vulnerable to a number of criticisms from positivist researchers. He further argues that case studies contend a lot of criticisms because they do not have the rigour of natural scientific designs. Case studies rarely allow generalization to be made from specific cases to the general population but produce huge piles of data that allows researchers to make interpretations they want.

Smith et al (2008, p. 97) contends that all case studies should have clear design produced before any data is collected and should cover the main questions or propositions, the unit of analysis, links between data and propositions and procedure for interpretation of data. 37

In sociological terms ontology refers to the fundamental beliefs individuals holds or as a society about the nature of SQTD (Buksa, 2008, p. 1).

Ontology is based on the assumption we make about the nature of reality (crotty, 2003). Thus, ontology relates to a researcher' $\mathrm{s}$ belief whether society is embracing sustainability in Vocational Training or not. Furthermore, to ensure the positivism and verification of facts in the case study the researcher had to use one hundred and fifty (150) questionnaires to examine three (3) selected public TEVET institutions within Lusaka. 
South American Journal of Management

Special Edition 2016

\section{Research Design Epistemology}

According to Bukisa (2008, pp. 1-2) Epistemology refers to the types and levels of proofs. Thus, proofs can be based on trust, faith, personal experience, logic and empirical evidence. Therefore, the epistemology suitable to use in this case study is a positivist research design which states that:

"Positivism Research methods usually incorporate the assumptions that there are true answers, and the job of the research is either to start with a hypothesis about the nature of the world, and then seek data to confirm or disconfirm it", (Smith, 2008, p. 84).

The key idea of positivism is that the world is governed by laws just like in natural science. Therefore, the task of sociologist is to discover the laws of behaviour of people for example in a given context (Bukisa, 2008, p. 2). In this study the researcher' s approach is based on the lookout for data and then adjusting the trend at the hand of the information gained from 150 questionnaires.

\section{Limitation of case study}

Ghosh (2008, pp. 227- 228) states that the case study method has some limitations and difficulties. Due to the following reasons:

1. In case study method, a researcher becomes over - confident. Since he/she studies various aspects of the life of an individual, he thinks that he knows everything about that person. But it is seen very often that many other aspects of life were hidden about which the respondent himself was ignorant.

2. Difficulties in Collection of Historical Data: Through this method proper data collection is very difficult. This is because generally the respondents do not reveal the actual facts to the researchers.

3. Expensive in Nature: The time and money required for this study are sometimes prohibitive.

\section{Instruments or tools of data collection}

In accordance with action research methodology the following tools or instrument were selected for the collection of the data:

\section{Questionnaires}

According to Ghosh $(2008$, p. 240) a questionnaire method is that method in which a number of printed questions are used for collecting data. In this study a structured questionnaire was selected. In structured questionnaire; contains definite, concrete and preordained questions. This type of questionnaire is prepared in advance and not on the spot during the questioning period.

\section{Pre - testing}

A pilot test of the questionnaire was performed at Lusaka Business and Technical College (LBTC) before focus group meetings took place. The structured questionnaires were piloted on ten (10) different people. However, these people were not involved in the full study, but were simply used as a comparable to participants in the full study (Ghosh, 2008). Thus, the pilot study allowed the researcher to identify any problems in the questionnaire, for instance misleading instructions or confusing questions. Hence, during the pilot study several misleading instructions were identified and rectified. After changing the instructions, the questionnaire was piloted again on the same group of people to see if there was any further problem.

\section{Population and sample size}

Stratification of the population size in twenty four (24) public TEVET institutions in Zambia that were perceived to provide the empirical data could not be captured due to geographical distances challenges, limited time and financial constraints. However, the 
researcher selected Three (3) public TEVET institutions within Lusaka because the researcher believed that the factors affecting Sustainable and Quality TVT in twenty four (24) public TEVET institutions were similar.

\section{Target Population and Sampling Size}

According to the case study one hundred and fifty (150) people were targeted as sampling of the study from Three (3) selected public TEVET institutions within Lusaka. Although, Lusaka as a capital city of Zambia has a population of 2 million people (Africa Travel Magazine"s Great Cities of Africa (ATMGCA), 2013). Out of this targeted population, the researcher prepared 150 structured questionnaires as shown in the appendix A for public TEVET lecturers in order to support the focus group discussion.

Additionally, qualitative data collected were supplemented by a structured- mixed questionnaire which consisted of open and closed questions. Thus, open questionnaire is used in cases where new facts are to be searched (Ghosh, 2008, p. 241). Thus, in this type of questionnaire a respondent is free to express his views and ideas. While closed questionnaire is used when categorized data are required. Here, the informant chooses the answer from a set of provided responses. Thus, the respondent has no liberty to express his own judgment (Appendix A). 39

\section{Interviews}

Interviews - Interviews have been considered as a very effective form of gathering information relating to understanding of phenomena. However, Ghosh (2008, p. 254) argues that the types of interviews can be classified according to subject matter of the study, purpose of the study and formalness of the study:

\section{According to Subject Matter}

According to the Methodology or subject matter the researcher selected Qualitative interview. Qualitative interview consists of certain complex, serious and non - quantifiable subject - matter.

This interview is confined to exploring the causes of some events. Sometimes it is called Diagnostic interview. However, although the researcher selected the qualitative interview, they are other types of interview:

(1) Quantitative interview; certain set facts are collected about a large number of persons, as in census.

(2) Mixed interview; is a method where both types of data are required. Some of the data may be quantifiable and some not.

\section{According to purpose}

Every interview is done with certain aim or purpose in view. In this case the researcher selected a Research Interview (RI) in order to collect information about factors affecting SQTVT in Zambia.

\section{According to Formalness}

According to for formalness of the study, the researcher used two main types of interviews in order to collect detailed information affecting SQTD in Zambia. Thus, the following are two main types of interviews:

(i) Structured interview;

(ii) Unstructured interview

Structured interview is a complete set of well - defined questions used in the questionnaire interview. In this method, highly standardized techniques of recording are used. In structured interviews, generally even the alternative questions are fixed. Thus, the interviewer has to act according to the written instructions given in the schedule. While in unstructured interview the interviewer / researcher does not follow a pre- planned list of questions. 
The researcher/interviewer enjoys full freedom to ask respondents. Thus, this type of interview was chosen due to the fact that the researcher had a deep knowledge and skill on the part of the study.

Nevertheless, in the opinion of Johan Gaultung, "the advantage of unstructured response is to be imprecise; that they permit the unexpected response" (Ghosh, 2008, p. 256).

\section{According to Number}

Group interview and individual interview were selected and facilitated by the researcher:

1. Individual Interview: In this type of interview a single individual is interviewed. Inter- personal contact between the interviewer and interviewee can be established.

2. Group interview: In this type of interview, a group of persons are interviewed for collecting information from them. This method economies both time and money (Ghosh, 2008, p. 257).

\section{Focus Group}

According to Bowling (2002, p. 394), focus groups are unstructured interviews with small groups of people who interact with each other and the group leader.

Kitzinger (1994, p. 103) defines Focus Groups as Group discussions organized to explore a specific set of issues. They have the advantage of making use of group dynamics to stimulate discussion, gain insights and generate ideas in order to pursue a topic in greater depth.

According to Kreuger and Casey (2000) the achievement and prospective of focus groups aroused interest among social scientists in the early 1980s, especially in applied research. Morgan and Spanish' s publication in 1984 drew attention to focus groups as a method for qualitative research in social sciences. Since then the growing success of this method is evident in Morgan' $\mathrm{s}$ estimate that social sciences journals are currently publishing more than 100 articles per year using focus groups" ( Colucci, 2007, p. 1423).

The 1990s witnessed focus groups methods gain standing in their use and the term itself becoming a mantra in a variety of fields. With this increasing popularity, there however emerged pseudo-controversy as to what really constitutes a focus group.

Affirming this viewpoint Linhorst (2002, p. 209) asserts that with the rise of focus group popularity "a lack of agreement emerged on what constitutes a focus group and there has been a tendency to mislabel many group activities to be focus groups". However, there is a general recognition of the character of contribution that focus groups make to social research such as organized discussion (Kitzinger, 1994, p. 103). 41

\section{Sampling strategy}

In accordance with action research Methodology the researcher selected the purposive sampling during the focus group meeting that took place at TEVETA headquarters as criteria of selecting ten (10) participants per session. Purposive sampling is a deliberately no-random method of sampling, which will aim to sample a group of people, or settings with a particular characteristic; usually in qualitative research designs.

It is also used in order to pilot questionnaires or generate hypothesis for further study. This is sometimes called judgment sampling, where respondents are selected because they have knowledge that is valuable to the research process. Thus, public TEVET Lecturers were selected within the case study to discuss the factors affecting SQTVT in Zambia.

\section{Administering of questionnaires}

Base on the above information, 150 structured questionnaires were prepared to interview public TEVET employees. The researcher managed to administer and analyze all 150 questionnaires. Thus, $100 \%$ responded successfully.

In table 5 below is a listing of three public TEVET institutions that were specific for case study. According to Kwortnik (2003), "a minimum sample size of twelve is suitable for 
qualitative research projects for which the main goal is deeper understanding of a phenomenon". Thus the sample was sufficient to meet the criterion.

Table 5 Schedule of Respondents involved in the public TEVET institutions case study:

\begin{tabular}{|l|c|l|l|l|}
\hline $\begin{array}{l}\text { Public } \\
\text { Staff }\end{array}$ & Questionnaire & $\begin{array}{l}\text { Gender } \\
\%\end{array}$ & $\begin{array}{l}\text { Completed Answering } \\
\%\end{array}$ & $\begin{array}{l}\text { Total Respondents } \\
\%\end{array}$ \\
\hline Female & $\checkmark$ & $26.7 \%$ & $26.7 \%$ & \\
\hline Male & $\checkmark$ & $73.3 \%$ & $73.7 \%$ & \\
\hline & & & $100 \%$ & $100 \%$ \\
\hline
\end{tabular}

Strengths and limitations of focus groups

A focus group method like all other research techniques presents both opportunities and challenges. In studying issues surrounding socially marginalized groups, focus groups have been found to be of great significance. They help elicit stories and in-depth explanations of people' $s$ thoughts and experiences and hence allow the researcher to observe different perceptions on an issue and understand what is salient about that issue (Church \& Rogers, 2006). This has an empowering effect on the part of the participants (Chambers, 2000), and consequently this builds trust in the group and wider community in general.

A central aspect of focus groups is the process of interaction. Kitzinger $(1994,1995)$ suggests that interaction within the group by way of speech or language, gestures and silences, is a fundamental aspect of focus group because it highlights their view of the world and their values and beliefs about a situation. Interaction also provides opportunity for participants to re-evaluate their specific experiences.

Lankshear (1993) affirms that if multiple understandings and meanings are revealed by participants, multiple explanations of their behaviour and attitudes will be more readily articulated.

\section{Why use focus groups for this study?}

The main reason for using focus group method in this research is to draw upon the participant' $\mathrm{s}$ attitudes, feelings, beliefs, experiences, and reactions in a way that would not be possible and reasonable through other methods such as questionnaire surveys. SQTD is the major challenge in all public TEVET institutions in Zambia. Thus, the researcher wished to carry out an investigation and identify the factors affecting SQTVT. While these factors affecting SQTD are likely to be discovered through social gathering which focus groups interaction facilitates.

An intrinsic value of focus groups is that the researcher, together with the respondents, become essential components of a system of co-learners and co-participants in a potentially transformational process of dialogue aimed at effecting "positive social change" (BrydonMiller, 1997, pp. 660-661).

The researcher observed that focus groups can enhance local people' $\mathrm{s}$ awareness and confidence and empower their action towards SQTD. This believes can occur when public TEVET lecturers and students participate and interact through dialogue in generating knowledge about SQTD. The researcher strongly believes that sustainable TEVET is an engine of economy. For instance Germany is one developed countries day because of Sustainable and quality TVT (Helmut Reutter, 2013).

In addition, using focus groups would help the researcher to obtain critical qualitative information on the levels and character of group "insights into the sources of complex behaviours and motivations" under respectful conditions for such "emotionally charged" discussions (Morgan \& Kreuger, 1993, pp. 16-18). Again, focus groups would allow the researcher to obtain larger volumes of data within a shorter period of time compared to observation, questionnaire surveys, or one-to-one interviews. 43 
South American Journal of Management

Special Edition 2016

\section{Ethical considerations of focus group}

Examinations of the literature on the use of focus groups in general and in particular, factors affecting SQTVT, revealed very little on the sustainable TEVET MBs, due to confidentiality of information in the operations of public TEVET institutions, besides the availability of the TEVET policy in place. It is for this reason that the researcher would wish to protect the names of participants by referring them as "respondents" as indicated in figure Francis (2005) and Smith (1995) echoed that privacy and confidentiality are essential concerns. This is for the reason that the focus groups process involves the sharing of information with both the researcher and other participants.

It is therefore important to ensure that the process is not damaging to the participants and, that participants are comfortable and free to tell information on the issue under study.

Vissandjee et al., conclude that "researchers have the obligation to reassure participants that their words will not come back to haunt them and will not be shared with family or other community members" (2002, p. 835). However, Smith (1995) indicated that the researcher can never totally ensure confidentiality as he/she cannot have control over what participants disclose to other community members once the focus group is over.

The general ethical principles governing the study will be that of the respondents to give informed consent to participate in the study. The consent will be in writing ( an agreement to participate and to be signed by the participants), and will be requested after they are given written information about the aims of the study, confidentiality and anonymity, and what it involves in relation to the participants (risks, discomfort, benefits, procedures, questionnaires).

Participants will be informed that they are free to withdraw at any time, and the researcher will answer any questions they may have about the study.

This voluntary consent will safeguard the freedom of the participants to choose to participate in the study or not and is intended to reduce the legal liability of the researcher. Permission to conduct the research will be sought from the University.

Observational processes tend to wait for things to happen naturally, whereas a focus group uses an interview guide with a group at a pre-determined time. Thus, the researcher used an interview guide in order to gather the empirical data. 44

\section{Data Analysis strategies}

In this study the researcher used the following data analysis strategies:

1. Qualitative Analysis of Content

2. Emerging themes

3. Coding

\section{Computer Support for Qualitative Content Analysis}

In this study SPSS software was used to support Qualitative content analysis and coding qualitative data analysis (see charts and graphs in chapter 4). However Qualitative content analysis and coding process are usually supported by computer programs, such as SPSS. The programs vary in their complexity and sophistication, but their common purpose is to assist researchers in organizing, managing, and coding qualitative data in a more efficient manner.

\section{Reliability of the research data}

Ultimately, the data collected is used to inform the research findings. If the data is not verifiable, the implication is that findings are potentially suspected. Thus, it is incumbent upon the researcher to validate his/her findings (Sekaran, 2003). Furthermore, a study is reliable only if another researcher, using the same procedure and studying the same phenomenon arrives at similar, comparable findings.

It is also important that the researcher maintains a comprehensive protocol of this study in case others may be interested in checking its reliability (Sekaran, 2003). 


\section{Trustworthiness}

Validity, reliability, and objectivity are criteria used to evaluate the quality of research in the conventional positivist research paradigm. As an interpretive method, qualitative content analysis differs from the positivist tradition in its fundamental assumptions, research purposes, and inference processes, thus making the conventional criteria unsuitable for judging its research results (Bradley, 1993, p. 436).

Recognizing this gap, Lincoln and Guba (1985) proposed four criteria for evaluating interpretive research work: credibility, transferability, dependability, and conformability.

Credibility refers to the "adequate representation of the constructions of the social world under study" (Bradley, 1993, p. 436).

Lincoln and Guba (1985) recommended a set of activities that would help improve the credibility of your research results: prolonged engagement in the field, persistent observation, triangulation, negative case analysis, checking interpretations against raw data, peer debriefing, and member checking. 45

To improve the credibility of qualitative content analysis, researchers not only need to design data collection strategies that are able to adequately solicit the representations, but also to design transparent processes for coding and drawing conclusions from the raw data. Coders" knowledge and experience have significant impact on the credibility of research results.

It is necessary to provide coders precise coding definitions and clear coding procedures. It is also helpful to prepare coders through a comprehensive training program (Weber, 1990).

The researcher is often confronted with a variety of variables which may impinge upon the reliability of his /her findings even though his/her intentions in minds mean well. Even if the researcher draws his/her conclusions on the basis of questionnaire and interview data, the feedback could be biased may be the respondents were in the mood not answer the questions with any degree of interest. However, research scholars advise researchers to carefully select their respondents that are willingly to participant in the study (Hair et al., 2005).

\section{Data Validation}

According to Saunders et al (2000) contends that a research is valid only if it actually studies what it set out to study and only if the findings are verifiable. Furthermore, Saunders et al. (2000) explains that constructing validity entails accurate operational measurements for the research' s core concept. Below are three methods for establishment validity:

1. A chain of evidence throughout the data collection process.

2. Verifying key information through the use of multiple sources of information.

3. Presenting informants with a draft of the study for review.

Yin (1989) argues that besides establishing construct validity researches need also to establish external validity by testing the applicability of the findings to external case studies.

\section{Conclusion}

Qualitative content analysis is a valuable alternative to more traditional quantitative content analysis, when the researcher is working in an interpretive paradigm.

The goal is to identify important themes or categories within a body of content, and to provide a rich description of the social reality created by those themes/categories as they are lived out in a particular setting. Through careful data preparation, coding, and interpretation, the results of qualitative content analysis can support the development of new theories and models, as well as validating existing theories and providing thick descriptions of particular settings or phenomena (Weber, 1990). 46 
South American Journal of Management

Special Edition 2016

\section{Research Findings and Discussion}

\section{Introduction}

This chapter includes empirical findings from the Public TEVET institutions" questionnaires completed during the focus group discussion and interviews by the respondents. Firstly it will provide analysis of Public TEVET lecturers" interviews. Furthermore, it will analyze the empirical findings from public TEVET MBs" semi-structured questionnaires.

\section{Research Finding}

Following the completion of transcriptions of all focus group discussions, the qualitative data was analyzed by structured techniques such as contents analysis, Emerging themes and coding (Huberman and Miles, 1994).

\section{Data Analysis Procedures}

The main research method for data analysis of this research is on factors affecting sustainable and quality TVT. In the provision of SQTD analysis the researcher included the use of focus group discussions for public TEVET lecturers and semi - structured interviews for public TEVET students in the action research methodology as a preliminary study. However, the tables will guide in the process of the empirical findings of this study.

\section{Analysis of public TEVET institutions interviews}

\section{The Researcher and Respondents}

In order to respect the anonymity of the interviewees, their names have been replaced with the word "respondent". The summary of interview responses is included in (Appendix A) a brief explanation in the following paragraphs.

Table 8 Do you think it is the good idea for the Government to abolish all management Boards in public TEVET institutions?

\begin{tabular}{|l|l|l|l|l|l|}
\hline & & Frequency & Percent & Valid Percent & Cumulative Percent \\
\hline \multirow{4}{*}{ Valid } & No & 45 & 30.0 & 30.0 & 30.0 \\
\cline { 2 - 6 } & Yes & 102 & 68.0 & 68.0 & 98.0 \\
\cline { 2 - 6 } & None response & 3 & 2.0 & 2.0 & 100.0 \\
\cline { 2 - 6 } & Total & 150 & 100.0 & 100.0 & \\
\hline
\end{tabular}

Although table 8 indicates that $68 \%$ lecturers wanted to abolish all MBs in 24 public TEVET institutions some other respondents indicated that MBs could remain and continue serving the administration staff such as principals, vice principals and financial managers as shown in cross tabulation table 10.

\section{Educational and Vocational Constraints and Opportunities}

According to Appendix A the researcher interviewed 150 employees from three public TEVET institutions and the findings were recorded according to the tables below:

Table 32 Do you have a TEVET Policy implementation monitoring mechanism in place?

\begin{tabular}{|l|l|l|l|l|l|}
\hline & & Frequency & Percent & Valid Percent & Cumulative Percent \\
\hline Valid & No & 101 & 67.3 & 67.3 & 67.3 \\
\cline { 2 - 6 } & Yes & 39 & 26.0 & 26.0 & 93.3 \\
\cline { 2 - 6 } & None response & 10 & 6.7 & 6.7 & 100.0 \\
\cline { 2 - 6 } & Total & 150 & 100.0 & 100.0 & \\
\hline
\end{tabular}

Table 32 indicates that not all 24 public TEVET institutions have a TEVET policy implementation monitoring mechanism in place. Thus, out of 150 total samples population interviewed $67.3 \%$ observed that MBs have not adequately enforced the TEVET policy implementation monitoring mechanism (Appendix A). 
Table 40 How often are TEVETA curricula revised and updated?

\begin{tabular}{|l|l|l|l|l|l|}
\hline & & Frequency & Percent & $\begin{array}{l}\text { Valid } \\
\text { Percent }\end{array}$ & $\begin{array}{l}\text { Cumulative } \\
\text { Percent }\end{array}$ \\
\hline Valid & After two years & 23 & 15.3 & 15.3 & 15.3 \\
\cline { 2 - 6 } & $\begin{array}{l}\text { After more than Two } \\
\text { years }\end{array}$ & 123 & 82.0 & 82.0 & 97.3 \\
\cline { 2 - 6 } & None response & 4 & 2.7 & 2.7 & 100.0 \\
\cline { 2 - 6 } & Total & 150 & 100.0 & 100.0 & \\
\hline
\end{tabular}

Table 40 indicates that due to inadequate funding by the Government TEVETA is unable to revise and update all curricula adequately. 48

Thus, out of 150 total samples population interviewed (82\%) confirmed the TEVETA curricula are out dated. Hence the industry is often ahead of the Vocational Training. Furthermore, TEVET graduates are unable to cope with new technology of the current industry.

Table 41 Do TEVETA curricula align with Zambian public Universities curricula?

\begin{tabular}{|l|l|l|l|l|l|}
\hline & & Frequency & Percent & Valid Percent & Cumulative Percent \\
\hline \multirow{3}{*}{ Valid } & No & 111 & 74.0 & 74.0 & 74.0 \\
\cline { 2 - 6 } & Yes & 28 & 18.7 & 18.7 & 92.7 \\
\cline { 2 - 6 } & None response & 11 & 7.3 & 7.3 & 100.0 \\
\cline { 2 - 6 } & Total & 150 & 100.0 & 100.0 & \\
\hline
\end{tabular}

Table 41 confirms that career progression has been a major challenge for TEVET graduates. Thus, out of 150 public TEVET employees interviewed $74 \%$ confirmed that the TEVETA curricula do not align with Zambian public universities. Furthermore, this response discloses why they are fewer degree holders" lecturers in all public TEVET institutions. TEVET graduates and their lecturers are facing similar challenges of career progression because Zambian public Universities are unwillingly to accommodate the TEVETA curricula and provide exemptions to TEVET graduates.

\section{Financial and Technology Challenges}

The researcher went further to interview 150 public TEVET employees from three public TEVET institutions in order to assess their financial and technology challenges. Below are tables disclosing the financial and technology challenges of public TEVET institutions:

Table 45 Does the Government fund the public TEVET institutions adequately?

\begin{tabular}{|l|l|l|l|l|l|}
\hline & & Frequency & Percent & Valid Percent & Cumulative Percent \\
\hline \multirow{4}{*}{ Valid } & No & 108 & 72.0 & 72.0 & 72.0 \\
\cline { 2 - 6 } & Yes & 30 & 20.0 & 20.0 & 92.0 \\
\cline { 2 - 6 } & None response & 12 & 8.0 & 8.0 & 100.0 \\
\cline { 2 - 6 } & Total & 150 & 100.0 & 100.0 & \\
\hline
\end{tabular}

Table 45 confirms why SQTD has been compromised since the introduction of MBs in all public TEVET institutions. For instance, out of 150 total samples population interviewed $(72 \%)$ disclosed that the Government does not adequately fund the public TEVET institutions.

Table 46 Does government funds for public TEVET institutions used adequately for intended purpose?

\begin{tabular}{|l|l|l|l|l|l|}
\hline & & Frequency & Percent & Valid Percent & Cumulative Percent \\
\hline \multirow{3}{*}{ Valid } & No & 124 & 82.7 & 82.7 & 82.7 \\
\cline { 2 - 6 } & Yes & 21 & 14.0 & 14.0 & 96.7 \\
\cline { 2 - 6 } & None response & 5 & 3.3 & 3.3 & 100.0 \\
\hline
\end{tabular}


South American Journal of Management

Special Edition 2016

\begin{tabular}{|l|l|l|l} 
Total & 150 & 100.0 & 100.0
\end{tabular}

Table 46 shows that public TEVET institutions do not use their funds for intended purpose, although the Government does not adequately fund them. Thus, $82.7 \%$ of public TEVET employees disclosed that there is a lot of misappropriation of Government funds in most of these institutions.

Table 47 Does the Ministry of Education and Science, Technology and Vocational Training and Early Education (MESTVTEE) addresses challenges of accountability in public TEVET institutions?

\begin{tabular}{|l|l|l|l|l|l|}
\hline & & Frequency & Percent & Valid Percent & Cumulative Percent \\
\hline \multirow{4}{*}{ Valid } & No & 100 & 66.7 & 66.7 & 66.7 \\
\cline { 2 - 6 } & Yes & 40 & 26.7 & 26.7 & 93.3 \\
\cline { 2 - 6 } & None response & 10 & 6.7 & 6.7 & 100.0 \\
\cline { 2 - 6 } & Total & 150 & 100.0 & 100.0 & \\
\hline
\end{tabular}

Table 47 indicates that the MESTVTEEE does not adequately address challenges of accountability in public TEVET institutions. More than half (66/7\%) respondents disagreed the MESTVTEE does not address challenges of accountability. Thus, this finding confirms why misappropriation funds do exist in public TEVET institutions. 50

Table 52 Does your institution have technologically latest equipment?

\begin{tabular}{|l|l|l|l|l|l|}
\hline & & Frequency & Percent & Valid Percent & Cumulative Percent \\
\hline \multirow{4}{*}{ Valid } & No & 129 & 86.0 & 86.0 & 86.0 \\
\cline { 2 - 6 } & Yes & 17 & 11.3 & 11.3 & 97.3 \\
\cline { 2 - 6 } & None response & 4 & 2.7 & 2.7 & 100.0 \\
\cline { 2 - 6 } & Total & 150 & 100.0 & 100.0 & \\
\hline
\end{tabular}

Table 52 shows vast majority respondents $(86 \%)$ confirmed that the public TEVET institutions do not have latest technological equipment.

Table 54 Does public TEVET management provides adequate training materials?

\begin{tabular}{|l|l|l|l|l|l|}
\hline & & Frequency & Percent & Valid Percent & Cumulative Percent \\
\hline \multirow{4}{*}{ Valid } & No & 120 & 80.0 & 80.0 & 80.0 \\
\cline { 2 - 6 } & Yes & 26 & 17.3 & 17.3 & 97.3 \\
\cline { 2 - 6 } & None response & 4 & 2.7 & 2.7 & 100.0 \\
\cline { 2 - 6 } & Total & 150 & 100.0 & 100.0 & \\
\hline
\end{tabular}

This table confirms why TEVET graduate are not practical oriented. Furthermore, $80 \%$ respondents disclosed that TEVET graduate are half baked because public TEVET management does not provide adequate training materials. 51

Table 55 Does accountability exit in public TEVET institutions?

\begin{tabular}{|l|l|l|l|l|l|}
\hline & & Frequency & Percent & Valid Percent & Cumulative Percent \\
\hline \multirow{4}{*}{ Valid } & No & 102 & 68.0 & 68.0 & 68.0 \\
\cline { 2 - 6 } & Yes & 43 & 28.7 & 28.7 & 96.7 \\
\cline { 2 - 6 } & None response & 5 & 3.3 & 3.3 & 100.0 \\
\cline { 2 - 6 } & Total & 150 & 100.0 & 100.0 & \\
\hline
\end{tabular}

In this table, $68 \%$ respondents confirmed that accountability does not exist in most of the public TEVET institutions.

\section{Economic and Social Constraints and Opportunities}

Below are tables recording the data and findings of the research concerning economic and social constraints and opportunities: 
Table 56 Are TEVET programmes offered in Zambia demand driven?

\begin{tabular}{|l|l|l|l|l|l|}
\hline & & Frequency & Percent & Valid Percent & Cumulative Percent \\
\hline \multirow{4}{*}{ Valid } & No & 106 & 70.7 & 70.7 & 70.7 \\
\cline { 2 - 6 } & Yes & 41 & 27.3 & 27.3 & 98.0 \\
\cline { 2 - 6 } & None response & 3 & 2.0 & 2.0 & 100.0 \\
\cline { 2 - 6 } & Total & 150 & 100.0 & 100.0 & \\
\hline
\end{tabular}

Table 56 shows that vast majority respondents agreed that TEVET programmes offered by TEVETA are not demand driven. 52

Table 57 Does your public TEVET institution align training delivery with Global labour market and suit to social - economic conditions?

\begin{tabular}{|l|l|l|l|l|l|}
\hline & & Frequency & Percent & Valid Percent & Cumulative Percent \\
\hline Valid & No & 101 & 67.3 & 67.3 & 67.3 \\
\cline { 2 - 6 } & Yes & 48 & 32.0 & 32.0 & 99.3 \\
\cline { 2 - 6 } & None response & 1 & .7 & .7 & 100.0 \\
\cline { 2 - 6 } & Total & 150 & 100.0 & 100.0 & \\
\hline
\end{tabular}

In this table public TEVET staff confirmed that public TEVET institutions offering training delivery does not align with Global labour market and suit to social - economic conditions.

Table 58 How do you compare the youth unemployment situation since the implementation of

TEVET policy?

\begin{tabular}{|l|l|l|l|l|l|}
\hline & & Frequency & Percent & Valid Percent & Cumulative Percent \\
\hline Valid & Very high & 37 & 24.7 & 24.7 & 24.7 \\
\cline { 2 - 6 } & High & 107 & 71.3 & 71.3 & 96.0 \\
\cline { 2 - 6 } & Low & 5 & 3.3 & 3.3 & 99.3 \\
\cline { 2 - 6 } & None response & 1 & .7 & .7 & 100.0 \\
\cline { 2 - 6 } & Total & 150 & 100.0 & 100.0 & \\
\hline
\end{tabular}

Table 58 confirms that there is high of unemployment among youths in Zambia since the implementation of 1996 TEVET policy. Thus, $71.3 \%$ respondents indicated that there is high of unemployment in Zambia. 53

Table 59 Are Lecturers/instructors skilled in sustainable and quality Technical and Vocational?

\begin{tabular}{|l|l|l|l|l|l|}
\hline & & Frequency & Percent & Valid Percent & Cumulative Percent \\
\hline Valid & No & 47 & 31.3 & 31.3 & 31.3 \\
\cline { 2 - 6 } & Yes & 102 & 68.0 & 68.0 & 99.3 \\
\cline { 2 - 6 } & None response & 1 & .7 & .7 & 100.0 \\
\cline { 2 - 6 } & Total & 150 & 100.0 & 100.0 & \\
\hline
\end{tabular}

Table 59 indicates that lectures/instructors are skilled in sustainable and quality technical and vocational training delivery. Thus, to avoid the high percentage of unemployment in Zambia, MBs and government must support public TEVET lecturers by providing adequate funding, training materials and latest technological equipment in all public TEVET institutions. Thus, $68 \%$ respondents agreed that lecturers have embraced sustainability in public TEVET institutions.

Table 60 In your own view, do you think University graduates are more recognized than TEVET graduates?

\begin{tabular}{|l|l|l|l|l|l|}
\hline & & Frequency & Percent & Valid Percent & Cumulative Percent \\
\hline \multirow{2}{*}{ Valid } & No & 40 & 26.7 & 26.7 & 26.7 \\
\cline { 2 - 6 } & Yes & 105 & 70.0 & 70.0 & 96.7 \\
\hline
\end{tabular}


South American Journal of Management

Special Edition 2016

\begin{tabular}{|l|l|l|l|l|l|}
\hline & None response & 5 & 3.3 & 3.3 & 100.0 \\
\cline { 2 - 6 } & Total & 150 & 100.0 & 100.0 & \\
\hline
\end{tabular}

Table 60 justifies why Government allocates more funding to higher institutions such as public Universities than Technical and Vocational Training. As show in the table $70 \%$ interviewees still feel that universities graduates are more recognized than TEVET graduates. 54

Table 61 Does your institution conduct attitude surveys to determine student satisfaction with TEVET programmes?

\begin{tabular}{|l|l|l|l|l|l|}
\hline & & Frequency & Percent & Valid Percent & Cumulative Percent \\
\hline \multirow{3}{*}{ Valid } & No & 133 & 88.7 & 88.7 & 88.7 \\
\cline { 2 - 6 } & Yes & 17 & 11.3 & 11.3 & 100.0 \\
\cline { 2 - 5 } & Total & 150 & 100.0 & 100.0 & \\
\hline
\end{tabular}

Table 61 indicates that out of 150 total samples population interviewed (88.7\%) confirmed that public TEVET institutions do not conduct attitude surveys to determine student satisfaction with TEVET programmes. Thus, these findings confirmed that although the MBs were introduced into all public TEVET institutions TQM and SQTD have not been adequately integrated into TEVET programmes.

Table 62 Do you have a quality assurance officer at your institution?

\begin{tabular}{|l|l|l|l|l|l|}
\hline & & Frequency & Percent & Valid Percent & Cumulative Percent \\
\hline \multirow{3}{*}{ Valid } & No & 10 & 6.7 & 6.7 & 6.7 \\
\cline { 2 - 6 } & Yes & 140 & 93.3 & 93.3 & 100.0 \\
\cline { 2 - 6 } & Total & 150 & 100.0 & 100.0 & \\
\hline
\end{tabular}

Table 62 indicates that most of the public TEVET institutions have quality assurance officers although the TQM and SQTD have not been adequately implemented into public TEVET MBs. Vast majority respondents (93\%) agreed that public TEVET institutions have quality assurance officers.

\section{Conclusion}

During the analysis of the public TEVET staff questionnaires based on focus group and indepth interviews it was noticed that the majority of response were not satisfied with the performance of the MBs in all public TEVET institutions. Therefore, this analysis indicates that there is a challenge to embrace SQTD in all public TEVET institutions. The respondents (public TEVET staff) also think that if MBs and public TEVET administrative organs could embrace sustainability as a life blood, public TEVET institutions would grow and move towards sustainable development. 55

The findings were presented in tables form using SPS software program. The next chapter is a discussion and analysis of the findings and relating of the findings in this literature review. 56

\section{Recommendations}

This chapter will present the general overview of the answers for conclusions and recommend possible solutions.

The following are recommendation needed to enhance SQPTD:

- Government should increase the funding for public TEVET institutions so that the institutions can have adequate training materials and training equipment.

- Government should employ qualified lecturers and they should pay them reasonable so that they may attract professional workforce.

- Good remuneration, good incentives and paid according to their salary scale.

- Need staff development programmes in order to enhance SQPTD in Zambia.

- Promotion should be on merit. 
- Need safety and health working environment

- The TEVET policy should be considered as the cross cutting issue at national level.

- Remove or abolish all the Boards in public TEVET institutions, they are not adding any value to the TEVET policy.

- People who reached the age of 55 should be retired to pave way for fresh thinking

- Change working culture and revise the curriculum and often move with time or technology so that Global requirements and needs are met. They should create programs that are adaptive to changing times and work with the industry.

- There is need for TEVET institutions to liaise with public universities on the issues of curricular.

- Take all public TEVET staff to Government payroll and all TEVET institutions should have uniform salary scale.

- Government should become aggressive in $M \& E$ of training programmes offered and also carry out detailed audit of these institutions to avoid personalizing resources at the expense of the majority labour force.

- Let quality assurance officers be part of management in their institutions.

- TEVET institutions should continue with their programmes.

- They should set high standard in their programmes, because the skills which they provide can help someone to become an entrepreneur.

- Identify what is required in the institutions in order to avoid misappropriation of government funds

- Public TEVET institutions need close supervision and sometimes shuffle the directors and accountants of institutions.

- Public TEVET institutions need network system suitable for M \& E system.

\section{References}

[1.] Abed, G. \& S. Gupta. 2002. „The economics of corruption: an overview“, in Abed, G. \& S. Gupta (eds). Governance, corruption and economic performance, New York: International Monetary Fund.

[2.] Abuarqub, M (2009), Islamic imperatives to curb corruption and promote sustainable Development: Islamic Relief worldwide, Birmingham.

[3.] Achebe, C. 1983. The trouble with Nigeria, London: Heinemann.

[4.] Achilles, C. M.; Lintz, M.N.; and Wayson, W.W. "Observations on Building Public Confidence in Education." EDUCATIONAL EVALUATION AND POLICY ANALYSIS 11 no. 3 (1989): 275-284.

[5.] Adedeji, A. 1990. The African alternative, Addis Ababa: ECA.

[6.] Ahluwalia, P. 2000. Politics and post-colonial theory: African reflections. Routledge: London.

[7.] Alesina, A. \& Weder, B. 2002. „Do corrupt governments receive less foreign aid?" American Economic Review, 92: 1126-1137.

[8.] Akyeampong, A. (2005), Vocationalisation of Secondary Education in Ghana in Lauglo, J and Maclean, R (eds) Vocationalisation of Secondary Education Revisited, UNEVOC/World Bank: Springer.

[9.] American Society for Information Science \& Technology, 55(3), 228-237.

[10.] Atchoarena, D. ans Delluc, A. (2002), Revisiting Technical and Vocational Education in sub Sahara Africa: an Update on Trends, Innovations and Challenges, UNESCO, IIEP.

[11.] Banach, Banach, and Cassidy. THE ABC COMPLETE BOOK OF SCHOOL MARKETING. Ray Township, MI: Author, 1996.

[12.] Bateman, Thomas s., and Snell, Scott A. (1996) Management: Building competitive advantage, London: Irwin.

$[58$

[13.] Bennel, P. (2007), Promoting Livelihood Opportunities for Rural Youth, Paper presented at Roundtable 3: Generating remunerative livelihood opportunities for rural youth, IFAD Governing Council 2007.

[14.] Berg, B.L. (2001). Qualitative Research Methods for the Social Sciences. Boston: Allyn And Bacon 
South American Journal of Management

Special Edition 2016

[15.] Black, Thomas R. (1993) Evaluating social science research, London: Sage.

[16.] Bishop, .G. (1985), Curriculum Development: A Textbook for students, London: Macmillian.

[17.]Bradley, F. (2003).Strategy Management in the customer driven Organization: London: Wiley.

[18.] Braun, A. R., J. Jiggins, N. Roling, Van den Berg, H. and P. Snijiders (2005), A Global Survey and Review of Farmer Field School Experiences. International Livestock Research Institute, Nairobi.

[19.] Braun, A. R., and Duveskog, D. (2008), The Farmer Field School Aproach - History, Global Assessment and Success Stories, Paper commissioned by IFAD (Draft 2008).

[20.] Brink and Berndt (2004).Customer relation management and customer service, Lansdowne: Juta.

[21.] Brodhead, C. W. "Image 2000: A Vision for Vocational Education." VOCATIONAL EDUCATION JOURNAL 66, no. 1 (January 1991): 22-25.

[22.] Brown, S. et al (2004), Strategic operations Management: Britain library: Norfolf.

[23.] Bunyi, G. W. (2004), Gender Disparities in Higher Education in Kenya: Nature, Extent and the Way Forward", Paper presented at the African Symposium Vol. 1, March 2004.

[24.] Buzzell, C.H. "Let Our Image Reflect Our Pride." VOCATIONAL EDUCATION JOURNAL 62, no. 8 (November-December 1987): 10.

[25.] Cammillieri, J. (2007), Le micro enterprise rurale en Afrique: De la survie a la croissance, le cas rwandais. L"Harmattan.

[26.] Carmody, B. (2004), The Evolution of Education in Zambia: Book world, Lusaka.

[27.] Charles, C.M. (1992), Building Classroom Discipline, 4th edn, London: Longman.

[28.] Charner, 1. (1996), study of School - to - Work Reform Initiatives, Washington, DC: Academy for Educational Development. ERIC Document Reproduction Service (Number 397 550).

[29.] Cole, G.A. (1997). Strategic management: Theory and Practice, 2nd Edition, London: Letts.

[30.] Cole, G.A. (1996). Management: Theory and Practice, 5th Edition, London: ELST-Continuum.

[31.] Commission on Africa, 2005. Our common interest, http://commissionforafrica.org (visited 12 March 2005).

[32.] Commonwealth of Learning (2001). Addressing the challenges of TVET. Vancouver, Canada: Author.

[33.] Curry and Kadasa, N (2002). Focusing on key elements of TQM- evaluation for sustainability: The TQM magazine, 14 (4), 207-216.

[34.] Dahl, J. (2003), Evaluating Distance Education in the 21st Century, Distance Education Report, 7(8): $4-5$.

[35.] Dale H. Besterfield et.al (2003) Total quality management: Pearson Prentice Hall, India.

[36.] Day, George S., Reibstein, David, J., and Gunther, Robert E. (Eds), (1997). Wharton on Dynamic competitive strategy, New Jersey: Wiley.

[37.] Denzin, Norman K (1970) the research act: A theoretical Introduction to sociological methods, Chicago: Aldine.

[38.] De Wever, B., Schellens, T., Valcke, M., \& Van Keer, H. (2006). Content analysis

[39.] East African Standard (2002), Financial Standard, Education Survey, 6 August, Nairobi: Standard Newspaper Limited.

[40.] Effectiveness for exploring cognitive behaviours. Journal of the American Society for Information Science, 51(8), 734-744.

[41.] Evans, R., Joel and Berman, B. (1990). Marketing. 4th edition, New York, Maxwell Macmillan.

[42.] FAO/WFP (2007), Getting started! Running a junior farmer field and life school. FAO/WFP, Rome, ltaly.

[43.] Fluitman, F. (2005), Poverty reduction, decent work, and the skills it takes or: towards correcting a partial view of training needs in African development.

[44.] Fluitman, F. (2002), unpublished plenary discussion on the draft of the World Bank"s Vocational Skills Development in Sub- Saharan Africa: Synthesis of regional review. Edinburg University, September 2002.

[45.] Fien J. et al. (2009). Work, Learning and Sustainable Development: Opportunities and Challenges. Dordrech: Springer.

[46.] Francis B. and Skelton. C. (2010), Investigating Gender: Contemporary perspective in Education. [47.] Freire, P. (2000), Pedagogy of the Oppressed, 30th anniversary edition, Continuum, New York. 
[48.] Foster, A. (2004). A nonlinear model of information-seeking behaviour. Journal of the

[49.] Galtung, F. 2005. "Measuring the immeasurable: Boundaries and functions of (Macro) corruption indexes", in F. Galtung \& C. Sampford (eds). Measuring corruption, London: Ashgat.

[50.] Gay. L. R. (1996), Education Research: Competencies for Analysis and Application, 5th Ed, New Jersey: Prentice Hall.

[51.] George. M., and Jones, G.R. (2006), Contemporary Management, creating value in organizations 4th Edition: Mc Graw Hill Irwin, Boston.

[52.] Ghosh. B.N., (2008), Scientic Method and Social Research: Sterling, Dehi-110020.

[53.] Godfrey B. and Charles J. (2002). Educational planning and Management in small States Concepts and Experiences: Published by the Commonwealth Secretariat. London SW1Y 5 HX, United Kingdom.

[54.] Hajedini, H and Roth, C., (2008), Combating corruption in Kosovo: UNDP Kosovo, Peyton place 14 , pristine.

[55.] Hannagan, T., (2008), Management Concepts and Practices 5th Edition: Pearson Education ltd England.

[56.] Hanlon, J. 1991, Mozambique: who calls the shots“, Oxford: James Currey.

[57.] Hanlon, J. 1996, Peace without profit: how the IMF blocks rebuilding in Mozambique, Oxford: James Currey

[58.] Hanlon, J. 2002. "Bank corruption becomes a site of struggle in Mozambique", Review of African Political Economy, 29(91): 53-72.

[59.] Hanlon, J. 2004. "eDo donors promote corruption? the case of Mozambique ${ }^{\text {ee }}$ Third World Quarterly, 25(4): 747-763.

[60.] Harsch, E. 1993. „Accumulators and democrats: Challenging state corruption in Africa ${ }^{\text {ee }}$ The Journal of Modern Africa Studies, 31(1): 31-48.

[61.] Hollenbeck, K. (1996), School - to - Work Programs to facilitate youth employment and Learning, Kalamazoo, MI: Upjohn Institute for Employment Research. (ERIC Document Reproduction Service Number 394 046)

[62.] Hope, K. 2000. Corruption and development in Africa, in K. Hope \& B. Chikulo (Eds.), Corruption and development in Africa: Lessons from country case studies, London: Macmillan.

[63.] Hussey, J., and Hussey R. (1997) Business research: A practical guide for undergraduate and postgraduate students, Hampshire: Palgrave.

[64.] IFAD (2008), Gash Sustainable Livelihoods Regeneration Project - Community Development and Capacity Building Component: Assessment of the Capacity Building Interventions and the Animal Health Agents.

[65.] IFAD (2007), Republicque du Mali, Eevaluation du programme de pays Rapport NO. 1905 - ML. [66.] IFAD (2005) UWESO Development, 2000 - 2005 - Program Completion Evaluation Report.

[67.] Information and communication University Study Manual (2012); Introduction to Microeconomics: School of Humanities Department of Economics.

[68.] James A. F.Stoner et.al (2007) Management: Pearson Prentice Hall India

[69.] Jobber, D. (2004). Principles and practice of marketing, 4th edition, London: Mc Graw Hill

[70.] Kankwenda, M. 2004. The AAF-SAP: first step on the African path to sustainable human development, in B. Onimode, et.al African development and governance strategies in the 21 st century, London: Zed Books.

[71.] Keefer, P \& Knack, S. 1995. „Institutions and economic performance: cross-country tests using alternative institutional measures ${ }^{\mathrm{ee}}$, Economics \& Politics, 7: 207-227).

[72.] Kerre, B.W. (1996), Promotion of Equal Access of Girls and Women to Technical and Vocational Education, Paris: UNESCO.

[73.] Kerre, B.W. (1995), Technical and Vocational Education in Africa: A Synthesis of Case Studies, Dakar: UNESCO.

[74.] Kerre, B.W. (2001), Science, Technology and Development, Paper presented to the Third World Studies (ATWS) Kenya Chapter Conference held at Egerton University, Kenya, 17 - 19 September 2001 . 
South American Journal of Management

Special Edition 2016

[75.] Kincheloe, Joe L. Toil and Trouble: Good Work, Smart Workers, and the Integration of Academic and Vocational Education. New York: Peter Lang Publishing. (1995)

[76.] Kincheloe, Joe L. How Do We Tell the Workers? The Socio-Economic Foundations of Work and Vocational Education. Boulder, CO: Westview Press. (1999)

[77.] King, E.M. and Hill, M.A. (1997), Attitudes of Trainees and Trainers Towards the $8-4-4$ Secondary Schools ${ }^{\text {ee }}$ Power Mechanics Subject in Kenya

[78.] King, K., McGrath, S. and Rose, P. (2007) Beyond the basics: Educating and training out of poverty, International Journal of Educational Development 27, 349 - 357.

[79.] King, K., and Palmer R. (2006), Skills Development and Poverty Reduction: The State of the Art. Centre of African Studies, University of Edinburgh.

[80.] Klasen, S. (2002), Insert of the Holy Grail: How to Achieve Pro - poor Growth? Munich: University of Munich, Department of Economics.

[81.] Kotler, P. (1999). Marketing: How to create win and dominate markets, London: FP-Free Press.

[82.] Kotler, P. (2003). Marketing Management, 11th edition, London: Prentice hall.

[83.] Kotler, P. (2003). Marketing Management, 11th edition, London: Prentice hall.

[84.] Koros, J.K. (2007), Learners "e Perception of Technical and Vocational Education in Kenya: A Case Study of Nakuru District, M. Phil Thesis; Moi University.

[85.] Lauglo, Jon; Maclean, Rupert (Eds.) "Vocationalisation of Secondary Education Revisited". Series: Technical and Vocational Education and Training: Issues, Concerns and Prospects, Vol. 1. Springer. (2005)

[86.] Lee, K. W. (2006), Effectiveness of government"s occupational skills development strategies for small - and medium - scale enterprises: A case study of Korea, international Journal of Educational Development 26 (2006) $278-294$.

[87.] Lockheed, M.E., Jamison, D.T. and Lau, L.J. (1980), "Farmer education and farm efficiency". In: Economic Development and cultural Change, 29, 37 - 76.

[88.] Matembe, M. (2010), Good Governance for Ombudsman and Anti corruption: CAFRA, Tangier, Morocco.

[89.] Mayoux, L. (2005), Learning and Decent Work for All: new directions in training and education for pro - poor growth InFocus Programme on Skills, Knowledge and Employability, ILO: Geneva.

[90.] Mayring, P. (2000). Qualitative content analysis. Forum: Qualitative Social Research, 1(2). Retrieved July 28, 2008, from http://217.160.35.246/fqs-texte/2-00/2-00mayring-e.pdf.

[91.] McGrath, S. (2005), The Challenge of Rural Skills Development. Debates in Skills Development, Paper 10, Working Group FOR International Cooperation in Skills Development. ILO/NORRAG/SDC: Geneva.

[92.] Michael, B. 2004. „What do African donor-sponsored anti-corruption programs teach us about international development in Africa?"e Social Policy and Administration, 38(4): 320-345.

[93.] Miles, M., \& Huber man, A.M. (1994). Qualitative Data Analysis. Thousand Oaks, CA: Sage Publications.

[94.] Minichiello, V., Aroni, R., Timewell, E., \& Alexander, L. (1990). In-Depth Interviewing

[95.] Ministry of Science Technology and Vocational Training: March 2005 -2012 Newsletters: Zambia.

[96.] Ministry of Science Technology and Vocational Training: March 2005 Newsletters: Zambia.

[97.] Ministry of Science Technology and Vocational Training: September 2005 Newsletters: Zambia.

[98.] Ministry of Science Technology and Vocational Training: September 2006 Newsletters: Zambia.

[99.] Ministry of Science Technology and Vocational: March 2007 Newsletters: Zambia.

[100.] Ministry of Science Technology and Vocational Training: January 2008 OAG -Newsletters: Zambia.

[101.] Ministry of Science Technology and Vocational Training: March 2008 Newsletters: Zambia.

[102.] Ministry of Science Technology and Vocational Training: March 2009 Newsletters: Zambia.

[103.] Moses O. Oketch (2006). School of Lifelong Education and International Development Institute of Education: University of London.

[104.] Munroe, M. (2002), Overcoming Crisis: Destiny Image, Bahamas. Allen, B., \& Reser, D. (1990). Content analysis in library and information science 
[105.] Munroe, M., (2005), Understanding your potential: Destiny, Bahamas.

[106.] Musaazi, J.C.S. (2001), Business, Technical and Vocational Education and Training (BTVET) as a Catalyst for Development in Africa; in The Status and Challenges of Business, Technical and Vocational Education and Training (BTVET) in Uganda (10 - 13) December 2001) Country report; Uganda.

[107.] Glaser, B.G., \& Strauss, A.L. (1967). The Discovery of Grounded Theory: Strategies for

[108.] Qualitative Research. New York: Aldine.

[109.] Hsieh, H.-F., \& Shannon, S.E. (2005). Three approaches to qualitative content analysis.

[110.] Qualitative Health Research, 15(9), 1277-1288.

[111.] Lincoln, Y.S., \& Guba, E.G. (1985). Naturalistic Inquiry. Beverly Hills, CA: Sage Publications.

[112.] Ndulo, M. 2003. „The democratization process and structural adjustment in Africae, Indiana Journal of Global Legal Studies, 10: 315-368.

[113.] Neuendorf, K.A. (2002). The Content Analysis Guidebook. Thousand Oaks, CA: Sage Publications.

[114.] O'Connor, P.J., and Trussell, S.T. "The Marketing of Vocational Education." VOCATIONAL EDUCATION JOURNAL 62, no. 8 (November-December 1987): 31-32.

[115.] OECD. (2008). more Than Just Jobs: Workforce Development in a skills Based economy.

[116.] Okaka, P.O. (1997), Technical and Vocational Education and Training Policy in Kenya: Under the Sun or in the Shade? Jua Kali in African Countries, Berlin: UNEVOC/UNESCO.

[117.] Okaka, P.O. (2001), Technical and Vocational Education and Training in Kenya, Paper presented on the sub - regional workshop on the theme Promotion and Reform of Technical and Vocational Education and Training in Africa, Kampala.

[118.] Onimode, B. 2004. Mobilization for the implementation of alternative development paradigms in 21 st century, in B. Onimode, et. al African development and governance strategies in the $21 \mathrm{st}$ century, London: Zed Books.

[119.] Op, de Beke, A. 2000. Anticorruption initiatives of the IMF. Joint ADB/OECD publication. Manila. http://www.oecd.org/document/28/0,2340,fr_2649_37447_1947036_1_1_1_37447,00.html (visited 14 March 2005)

[120.] Palmer, R. (2007) Skills for work? From skills development to decent livelihoods in Ghana rural informal economy. International journal of Education Development 27 (2007) 397-420.

[121.] Patton, M.Q. (2002). Qualitative Research and Evaluation Methods. Thousand Oaks, CA: Sage.

[122.] Picasso, P. (1966). Quoted in Hélène Parmelin, “Truth," In Picasso Says. London: Allen \& Unwin (trans. 1969).

[123.] Porter, Michael E. (1980). Competitive strategy. Techniques for analyzing industries and competitors, London: FP Free Press.

[124.] Porter, Michael E. (2004). Competitive Advantage. Creating and sustaining superior performance, London: FP Free Press.

[125.] Schamber, L. (2000). Time-line interviews and inductive content analysis: Their

[126.] Schamber, L. (1991). Users"e Criteria for Evaluation in Multimedia Information Seeking and Use Situations. Ph.D. dissertation, Syracuse University.

[127.] Schilling, J. (2006). On the pragmatics of qualitative assessment: Designing the process for content analysis. European Journal of Psychological Assessment, 22(1), 28-37.

[128.] Smith, D. „Kinship and corruption in contemporary Nigeria ${ }^{e e}$ Ethnos, 66(3): 344-364.

[129.] Smith, H.W. (1975). Strategies of Social Research: The Methodological Imagination. Englewood Cliffs, NJ: Prentice-Hall.

[130.] Reeves, Diane Lindsey CAREER ACADEMY TOOLKIT. Raleigh, North Carolina: Bright Futures Press, 2006.

[131.] Richard G. Lipsey e.tal (2004) Economic; Oxford university press inl. New York.

[132.] Ries, E. "To 'V' or Not to 'V': for Many the Word 'Vocational' Doesn't Work." TECHNIQUES 72, no. 8 (November-December 1997): 32-36.

[133.] Ries, A., and Trout, J. THE 22 IMMUTABLE LAWS OF MARKETING. New York: HarperCollins Publishers, 1993. 
South American Journal of Management

Special Edition 2016

[134.] Riley, S. 2000. „Western politics and African realities: the new anti-corruption agendae, in K. Hope \& B. Chikulo (eds). Corruption and development in Africa: lessons from country case studies, London: Macmillan.

[135.] Robbins, S.P., and Couter, M. (2007), Management 9th Edition: Pearson Prentice Hall, New Jersey.

[136.] Roeske, J. (2003). Skills training strategies to combat worst forms of child labour in formal economy: Ghana country study. Marseilles, France: International Programme on the Elimination of Child Labour (IPEC).

[137.] Rowan, L., et al (2002), Boys literacies and schooling: library of Congress Cataloging in publication Data.

[138.] Sakala, R. (2000), Beyond Political Rhetoric: ZPC, Lusaka.

[139.] Saunders, M., Lewis, P., and Thorn hill, A. (2003). Research methods for business students, 3rd edition, London: FT Prentice Hall.

[140.] Sharpe, D. "Image Control: Teachers and Staff Have the Power to Shape Positive Thinking." VOCATIONAL EDUCATION JOURNAL 68, no. 1 (January 1993): 26-27.

[141.] Shields, C.J. "How to Market Vocational Education." CURRICULUM REVIEW (November 1989): 3-5

[142.] Silberman, H.F. "Improving the Status of High School Vocational Education." EDUCATIONAL HORIZONS 65, no. 1 (Fall 1986): 5-9.

[143.] Smith, S.E. (2012), WiseGeek: Conjecture Corporation.

[144.] Simiyu, J. (2007), Introducing elearning as a strategy to increase Enrolment in TVET, Paper presented at the 1st African UNESCO - UNEVOC Summit on Access and Inclusion for TVET in Africa through New ICT - Based Solutions, 28 - 30 May, Safari Park Hotel, Nairobi, Kenya.

[145.] Stan lake"s SJ Grant (2006); Introductory Economics: Person Education Limited, Inc. New Jersey.

[146.] Stephen P. Robbin et .al (2007) Management: Pearson Education, Inc.New Jersey

[147.] Stern, Carl W., and Deimler, Michael S. (2006). The Boston consulting group on strategy: Classic concepts and new perspectives, 2nd Edition, New Jersey: Wiley.

[148.] Stokes, D. (1997). Marketing: A case study approach, 2nd edition, London: Continuum. [149.] Stoner, F. et al (2009), Management 6th Edition: Pearson Education, Delhi 110092, India. [150.] Stuart .W .R. et al (2005); Business Economics: Pearson Education Limited Edinburgh Gate. [151.] Swarland, J.R. (2000), learning for life, Work and the Future Stimulating Reforms in Southern Africa through Sub - regional Cooperation, Workshop Paper, UNEVOC/UNESCO/Ministry of Education, Botswana.

[152.] Taylor, W.A. and Wright, G.H., (2003), a longitudinal study of TQM implementation: factors influencing success and failure, Omega, 31, $97-111$.

[153.] Taneja, V.R. (2012), Educational Thought and Practice: Sterling, New Delhi 110092, and India.

[154.] Technical Education and Vocational Entrepreneurship Training: April 2003 Newsletters: Zambia.

[155.] Technical Education and Vocational Entrepreneurship Training: September 2005 Newsletters: Zambia.

[156.] Technical Education and Vocational Entrepreneurship Training: December 2006 Newsletters: Zambia.

[157.] Technical Education and Vocational Entrepreneurship Training: April 2009 Newsletters: Zambia.

[158.] Technical Education and Vocational Entrepreneurship Training: March 2009 Newsletters: Zambia.

[159.] Technical Education and Vocational Entrepreneurship Training: March 2010 Newsletters: Zambia.

[160.] Technical Education and Vocational Entrepreneurship Training: March 2011 Newsletters: Zambia.

[161.] Technical Education and Vocational Entrepreneurship Training: December 2011 Newsletters: Zambia. 
[162.] Technical Education and Vocational Entrepreneurship Training: March 2012 Newsletters: Zambia.

[163.] Technical Education and Vocational Entrepreneurship Training: September 2007 Newsletters: Zambia.

[164.] Technical Education and Vocational Entrepreneurship Training: December 2008 Newsletters: Zambia.

[165.] Technical Education and Vocational Entrepreneurship Training: April 2010 Newsletters: Zambia.

[166.] Technical Education and Vocational Entrepreneurship Training: March 2010 Newsletters: Zambia.

[167.] Technical Education and Vocational Entrepreneurship Training: March 2010 Newsletters: Zambia.

[168.] Technical Education and Vocational Entrepreneurship Training: March 2013Newsletters: Zambia.

[169.] Technical Education and Vocational Entrepreneurship Training: April 2013 Newsletters: Zambia.

[170.] Tesch, R. (1990). Qualitative Research: Analysis Types \& Software Tools. Bristol, PA: Falmer Press.

[171.] Thiagarajan, .T. and Zairi, M., (2001), A proposed model of TQM implementation based on an empirical study of Malaysian industry, International Journal of Quality \& Reliability management, 19 (5), $508-523$.

[172.] Tim Hamagan (2008). Management Concept and Practices: Pearson Education Ltd, prenticed Hall

[173.] Tuttle, F.T. "Let's Get Serious about Image-Building." VOCATIONAL EDUCATION JOURNAL 62, no. 8 (November-December 1987): 11.

[174.] UNESCO (2004) Synthesis report: improving access, equity and relevance in technical vocational education and training (TVET). Bangkok, Thailand: UNESCO.

[175.] UNEVOC (2000), learning for Life, Work and Future: Stimulating Reform in Southern Africa through Sub regional Co - operation, Gaborone: UNESCO.

[176.] UN Conference for Sustainable Development. 2010. United Nations Conference for Sustainable Development Rio 20. Available FROM Http:/WWW. Uncsd2010.org/index.php?option= com_content\&id=91: the- history- of-sustainable-development-in-the-unitednations\&catid=55\&ltemid-99(accesed 07 February 2011).

[177.] UNECE n.d.United Nations Economic Commission for Europe. Htt://WWW.unece.org/env/pp/ (Accessed 16 February 2011)

[178.] UNESCO - ILO (2002), Technical and Vocational Education and Training for the Twenty - first Century, UNESCO and ILO Recommendations.

[179.] UNESCO - UNEVOC (2006), Participation in formal technical and vocational education and training programmes worldwide: an initial stastical study. Bonn, Germany. UNESCO - UNEVOC International centre for technical and vocational education and training.

[180.] UNESCO Institute for Statistics (2007), Participation in Formal Technical and Vocational Education and Training Programmes Worldwide - An Initial Stastical Study. Montreal, Canada.

[181.] UNESCO.2010.Education for sustainable development (ESD). HTTP//WWW.unesco.org/en/esd/ (January 2011)

[182.] Utstein Anti-corruption Resource Centre, 2005. Anti-corruption projects by agency http://www.u4.no/projects/agency.cfm (visited 31 March 2005).

[183.] US General Accounting Office, 2004. Foreign assistance. US anticorruption programs in subSaharan Africa will require time and commitment, Report to the subcommittee on African Affairs, committee on foreign relations, US Senate, GAO-04-506, pp. i-67.

[184.] Van den Berg, H. (2004). IPM Farmer Schools: A synthesis of 25 impact evaluations. Wageningen. University. $53 \mathrm{pp}$.

[185.] Van Der Wieele, T. and Brown, A., (2002), Quality management over a decade: A longitudinal study, International Journal of Quality \& Reliability management, 19(5), 508 - 523. 
South American Journal of Management

Special Edition 2016

[186.] Watter J. Wessels 2006; Economic; Library of Congress Cataloging in - publication Data.

[187.] Weber, R.P. (1990). Basic Content Analysis. Newbury Park, CA: Sage Publications.

[188.] "What Do People Think of Us?" TECHNIQUES 72, no. 6 (September 1997): 14-15.Asian Academy Of Film \& Television

[189.] Williams, R., et, al (2004), TQM: why it will again become a top management issue, International Journal, 6(4), $314-330$.

[190.] Wolfensohn, J. 2000. Letter to B. Nelson, US General Accounting Office, 16 March. Washington, DC.

[191.] Woon, K.C., (2000), Assessment of TQM implementation: Benchmarking Singapore"s productivity leaders, Business Process Management Journal, 5(4), 314 - 330.

[192.] World Bank, FAO, IFAD (2008), Gender in Agriculture Sourcebook. Washington DC. The International Bank for Reconstruction and Development. The World Bank.

[193.] World Bank, 2005, "Ten things you never knew about the World Bank in Africae, http://www.worldbank.org/tenthings/AFR/1-afr.htm (visited 1 April 2005).

[194.] World Bank (2004), Skills development in Sub - Saharan Africa. World Bank, Washington DC.

[195.] World Bank (2000), Engendering Development Though Gender Equality in Rights Resources and Voice. Washington DC: World Bank.

[196.] World Bank (2000), Attacking Poverty: World Development Report 2000 - 2001 Oxford: Oxford University Press.

[197.] Yusof, S.M. and Aspinwall, E., (2000a), A conceptual framework for TQM implementation for SMEs, the TQM magazine, 12(1), $31-36$.

[198.] Yusof, S.M. and Aspinwall, E., (2000b), TQM implementation issues: review and case study, International Journal of operations and production management, 20(6), $634-655$.

[199.] Yusof, S.M. and Aspinwall, E., (2001), Case studies on the implementation of TQM in the UK automotive SMEs, International Journal of Quality \& Reliability Management, 18(7), 722 - 743.

[200.] Zairi, M. \& Liburd, I. M., (2001), TQM sustainability - a roadmap for creating competitive advantage, Integrated Management, Proceedings of the 6th International conference on ISO 9000 \& TQM, Paisely, Ayr, Scotland, 17 - 19 April, 452 - 461 (Hong Kong Baptist university press) ISBN $962-86107-2-4$.

[201.] Zairi, M., (2002), Beyond TQM implementation: the new paradigm of TQM sustainability, Total Quality management, 13(8), $1161-1172$. 